\title{
Identification of Building-Surrounded Obstacle Parameter Using Automated Simulation to Support Building Integrated Photovoltaic (BIPV) Layout Planning in Thailand
}

\author{
Nuttasit Somboonwit ${ }^{1} \&$ Amon Boontore ${ }^{1}$ \\ ${ }^{1}$ Faculty of Architecture, King Mongkut's Institute of Technology Ladkrabang (KMITL), Bangkok, Thailand \\ Correspondence: Nuttasit Somboonwit. E-mail: nuttasit.somboonwit@gmail.com
}

Received: October 3, 2017

Accepted: October 16, $2017 \quad$ Online Published: November 28, 2017

doi:10.5539/ass.v13n12p142

URL: https://doi.org/10.5539/ass.v13n12p142

\begin{abstract}
The overall aim of this study was to explore the comparative effects between obstacle's distance and obstacle's orientation parameters that cause partially shading effects and influence the potential solar power generation of a photovoltaic (PV) system. An automatic collaboration of a BIM authoring software and a cloud-based building performance analysis tool were used to simulate the annual cumulative insolation obtained from rooftop PV surfaces of eight different orientations and forty-three different distances between the BIPV and building obstacle. Two public healthcare buildings, an OPD and a ward building that widely established throughout Thailand were our case study. This study also explores that orientation and distance of a surrounding obstacle are both important parameters that influencing the annual cumulative insolation of PV surfaces but in the different contexts. The findings of this study also support decision making for BIPV designers and planners to acknowledge which the BIPV and the obstacle placement is highly effective, and which one is encountering a problem and its solution.
\end{abstract}

Keywords: surrounding obstacle, partial shading effect, building integrated photovoltaic, automated simulation, obstacle's orientation, obstacle's distance

\section{Introduction}

\subsection{Introduction of the Problem: Building Integrated Photovoltaic (BIPV)}

The sun is the widest and huge amount of expansive energy source. The potential for solar energy to make a significant contribution to global electricity demand has been widely recognized and solar photovoltaic (PV) is considered as a major contributor to solar energy supply (Ekici, 2014; Yang, 2015). Photovoltaic systems are one of the most beneficial plants in this clean electricity production which is easy to install in and apply to a building and an urban environment. Building integrated photovoltaics (BIPVs) are solar PV materials that replace conventional building materials in parts of the building envelopes, such as the rooftop or walls, that serve as building envelope material and power generator simultaneously. Additionally, the BIPV technology also reduces the total building cost and mounting cost as BIPV panels serve as building components (Shukla, et al., 2016; Hong, Lee, Koo, Jeong, \& Kim, 2017; Tripathy, Yadav, Sadhu, \& Panda, 2017). Apart from attaining optimum technique and aesthetic solutions. Other key factors to achieve wide-scale implementation of BIPV involve minimizing the production costs, reducing the environmental impact and especially increasing the final efficiency of the system (Mulcué-Nieto \& Mora-López, 2015). The efficiency of any BIPV systems can be estimated by solar insolation, i.e., a measure of solar radiation energy received on a specific PV surface area at a given time. Solar insolation is affected by factors such as atmosphere, angle of the sun and distance. The thinner the atmosphere in which the sun is passing through, the higher degree the insolation. The insolation of an area determines how much energy a square meter of solar panel can provide on any given day. When the insolation rate of an area is low, more area of panel is required to maximize energy output (Sinovoltaics, 2014). A BIPV system directly converts sunlight into electricity so it is sensitively affected with the change in the intensity of solar radiation. These fluctuations cause troubles between demand and supply and reduce the power quality (Ekici, 2014). Main challenging issues about BIPV applications including partial shading, incorrect specifications of the BIPV systems, non-optimal tilt and azimuthal deviations are commonly encountered: therefore, the importance of these technical performance issues is indisputable, particularly in designing processes (Lam, Close, \& E.W.C., 2006; Celik, Karatepe, Silvestre, Gokman, \& Chouder, 2015; Yang, 2015; Zomer \& Rüther, 2017).

\subsection{An Introduction to the Partial Shading Effects}

PV system performance is significantly affected by the environmental and surrounding factors which involve; surrounding-reflected radiation and shading effects of the environmental obstacles (Yoo, 2011; Celik, Karatepe, Silvestre, Gokman, \& Chouder, 2015). The available total solar irradiance on PV modules is composed of three components: beam (direct), diffuse from sky, and surrounding-reflected components. Beam radiation is the component directly comes from the sun without being scattered through the atmosphere but diffuse radiation is highly scattered by 
different types of particles of clouds, dust or haze in the atmosphere. Beam radiation calculation is purely geometric and directly dependent upon the solar geometry-azimuth and altitude, straightforwardly. On the other hand, surrounding-reflected radiation is a complicated factor which is structurally formulated by both beam and diffuse radiation reflected from the surrounding such as nearby buildings and ground, and reach the PV module again. The surrounding-reflected radiation also depends on many factors such as surrounding reflectance, absorptance, emittance, and transmittance which influences the incidence solar irradiation on the PV modules (Yoo, 2011; Gökmen, 2016).

Practically, one of the most significant and complicated effect in dealing with BIPV performance estimation is the partial shading effect on PV modules due to the surrounding obstacles, it plays important role in the efficiency of PV systems by their convoluted, non-uniform and dynamic conditions, especially when the PV system locates in a dense urban environment. Partially shaded PV modules receive less solar radiation than the unshaded PV modules and partial shading effects may cause irreversible damage to the module due to the hot spot effect. The surrounding obstacles including trees, utility poles, surrounding buildings and so on, furthermore, only the building itself on which the system is integrated is responsible for approximately 5-10\% decrease of the overall BIPV performance (Celik, Karatepe, Gokman, \& Silvestre, 2013; Masa-bote \& Caamaño-Martín, 2014; Frontini, Bouziri, Corbellini, \& Medici, 2016; Zomer \& Rüther, 2017).

To acknowledge the impacts of the shadow that project on the surfaces of a PV system, examination of three main conceptual parameters are required including (A) solar properties, (B) surroundings, and (C) related-BIPV which are described as follow (Yoo, 2011; Celik, Karatepe, Gokman, \& Silvestre, 2013; Masa-bote \& Caamaño-Martín, 2014):

(A) The parameter of solar property includes (A-1) the sun altitude, (A-2) azimuth angle, and (A-3) solar irradiation. The radiant energy from the sun is measured and reported as the solar irradiance, it is a crucial parameter using for calculating the solar insolation of PV modules (Zeil, 2017).

(B) The parameter of surroundings consists of two subcategories; (B-1) the parameter of surrounding-reflected radiation and (B-2) surrounding obstacle. The parameter of surrounding-reflected radiation includes (B-1-1) reflectance, (B-1-2) absorptance, (B-1-3) emittance and (B-1-4) transmittance as previously described, while (B-2) the parameter of a surrounding obstacle comprises of (B-2-1) obstacle's location, (B-2-2) obstacle's shape, and (B-2-3) obstacle's orientation, (Figure 1). The surrounding obstacles block and eliminate the beam element of the solar radiation from fully hitting on a PV surface. The projected shadow from the three-dimensional coordinates of the obstacle on PV surfaces determined by the solar azimuth and solar altitude angles that dynamically change all the time during day. The dynamical variation makes the parameters of a surrounding obstacle one of the subtlest factors; however, clarification of such parameter assists in a more accurate estimation of partial shading effects.

(C) The parameter of related-BIPV consists of two subcategories: (C-1) the parameter of a PV surface geometry includes (C-1-1) PV surface orientation, (C-1-2) PV surface tilt angle, (C-1-3) PV surface shape, and (C-1-4) PV surface location, these four parameters are illustrated, in relation with the parameter of a surrounding obstacle, in Figure 1. (C-2) the parameter of a PV module properties comprises of (C-2-1) PV materials, (C-2-2) BIPV product type, and (C-2-3) BIPV system type. PV materials which are semiconductors create voltage and current from movement of electron between anode and cathode poles to generate electricity. There are two broad categories of PV cells technologies - Crystalline Silicon and Thin Film. Crystalline Silicon cells gain the majority of market share at almost 90 percent of the world's PV materials and they provide efficiency of 12-16\% (Chaianong \& Pharino, 2015; Shukla, Sudhakar, \& Baredar, 2016). BIPV products are classified into five main categories including: (1) BIPV's foil products, (2) BIPV's tile products, (3) BIPV's module products, (4) BIPV's solar cell glazing products and (5) building attached photovoltaic (BAPV) products. In the current BIPV market application, about $80 \%$ of BIPV installations are rooftop mounted, while the remaining $20 \%$ are façade mounted. Rooftop solar PV systems generally and practically meet requirements of most cases where ground space is limited and unused large roof space is available.

Similarly, in Thailand, many BIPV end-users have gained greater interest in the solar rooftop technology especially rooftop BIPV's module products due to their high efficiency performance, competitive pricing among suppliers, easily applicable and suitable for pitched roofs. The rooftop BIPV solar PV module products may be somewhat similar to conventional solar PV modules. The difference, however, is that the BIPV solar modules are made with weather skin solutions (Jelle, Breivik, \& Røkenes, 2012; Chaianong \& Pharino, 2015; Shukla, Sudhakar, \& Baredar, 2016). A BIPV system - (C-2-3) is considered as building integrated energy storage system which is comprised of a charge controller, a power storage system, power conversion equipment including an inverter, and it may include backup power suppliers such as diesel generators (Strong, 2011; Biyik, et al., 2017).

As previously mentioned, the projection of shadow on the PV modules has been determined by using the three-dimensional coordinates that derived from the parameters of the surrounding obstacle which are determined by solar azimuth and solar altitude angle that constantly change through time. The projection of shadow on PV modules directly determines the shaded PV surfaces, shown in Figure 2, that have been dynamically and continuously changed by the movement of the sun.

Figure 3 illustrates an example of dynamic change of shadow at 2.30 p.m. and 3.30 p.m. on winter solstice for buildings located in Bangkok, Thailand $\left(13^{\circ} \mathrm{N} 100^{\circ} 30^{\prime} \mathrm{E}\right)$, east facing $\left(\mathrm{AZ}=90^{\circ}\right)$. Figure 3(a) and 3(b) show a BIPV (on the right), in which the shade comes from a nearby building (a surrounding obstacle). Point A and point B are 
examples of three-dimensional coordinates that represent obstacle's location, while point $\mathrm{C}$ and point $\mathrm{D}$ are the shadow points on the rooftop PV surfaces that are determined from point A and point B in relation with the solar azimuth and altitude angles. While the locations of the surrounding obstacle (point A and point B) and the BIVP has been fixed, it can be clearly seen that an hour of time difference, between 2.30 p.m. and 3.30 p.m., the shadow points (point $\mathrm{C}$ and point D) have been moved with a distance and area and shape of the shaded PV surface has been changed greatly, as shown in Figure 3(c) and 3(d). This shift of projected shadow significantly changed the level of received solar irradiation of the associated PV surfaces (Ning et al., 2017).

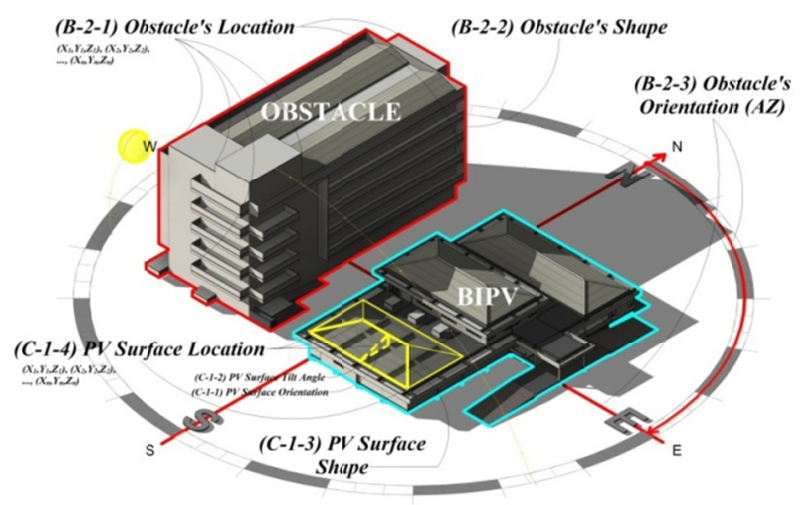

Figure 1. An ilustration of the parameter of a surrounding obstacle (B-2) and the parameter of a PV surface geometry (C-1)

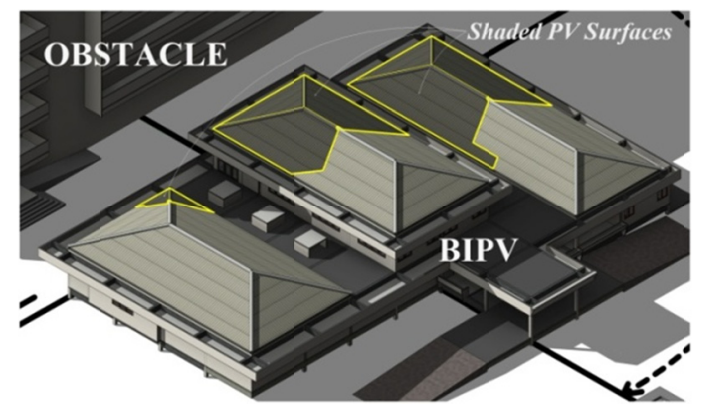

Figure 2. Example of complex shapes projection of shadow on the shaded PV surfaces
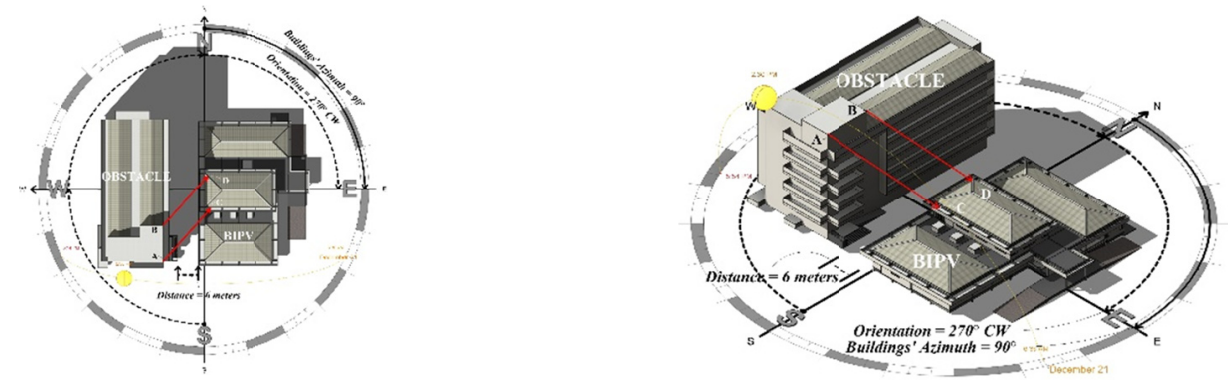

(a)

(b)

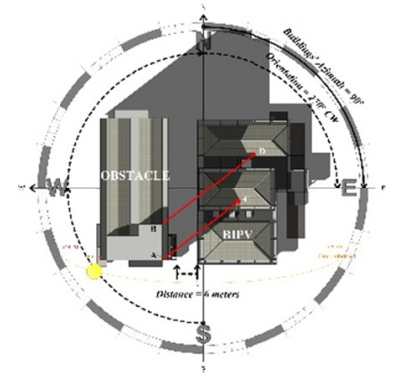

(c)

(d)

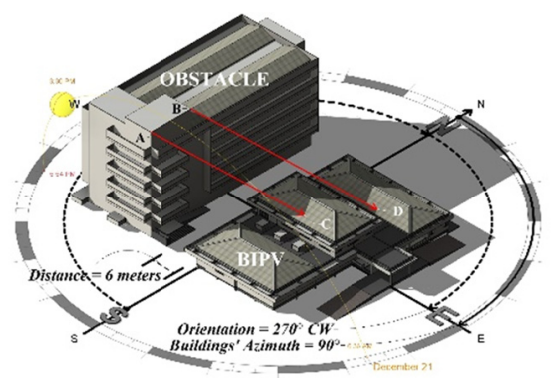

Figure 3. A dynamic change of projected shadow at 2.30 p.m. and 3.30 p.m. on winter solstice 
Summarily, the impacts of the partial shading effects on the potential of power generation of a PV system can be calculated using the parameters of solar properties, surrounding and PV modules, which the result is the effective irradiance over a time period that called the solar insolation, as mentioned earlier in section 1.1, over PV surfaces. The conceptual relationships among them are displayed in Figure 4.

\subsection{Statement of the Problem: The Surrounding Obstacle}

Partial shading effect is an unavoidable condition in BIPV systems, and it can be seen from Figure 4 that such effect is principally influenced by two groups of parameters - 1) PV surface geometries and 2) surrounding obstacle. Numerous studies have examined the parameter of PV surface geometries (Norton, et al., 2011; Yoo, 2011; Alam, Coors, Zlatanova, \& Oosterom, 2012; Celik, Karatepe, Gokman, \& Silvestre, 2013; Masa-bote \& Caamaño-Martín, 2014; Kanters \& Wall, 2014; Celik, Karatepe, Silvestre, Gokman, \& Chouder, 2015; Eke \& Demircan, 2015; Hong, Lee, Koo, Jeong, \& Kim, 2017; Tripathy, Yadav, Sadhu, \& Panda, 2017; Zomer \& Rüther, 2017), while the investigation of the parameter of surrounding obstacles (Celik, Karatepe, Gokman, \& Silvestre, 2013; Kanters \& Wall, 2014; Kanters, 2015) is still meager. Consequently, this study focuses on the parameter of surrounding obstacle determining the projection of shadow on PV surfaces. No matter what kind of obstacles that surround the BIPV they are, trees, electricity poles, buildings and so on, when considering a nearby building obstacle, not only is it out of BIPV owner's authority, but it is normally also not available for major alteration of its three-dimensional shape due to its variety of designated functions and aesthetic reason, not to mention the case that such building is not under the BIPV owner's authority. Furthermore, apart from time and resource consuming, pursuing the optimum shape of a surrounding building tends to give impractical outcome.

Besides the obstacle's shape, the shadow projected on BIPV obtained as shaded PV surfaces is determined in terms of the solar azimuth, altitude angles and surrounding obstacle's location and orientation. Obstacle's location is assumed to be composed of point particles (three-dimensional coordinates) interacting with a BIPV, i.e., through the proxy of distance between two buildings. Obstacle's orientation refers to both the direction that BIPV faces towards and the location of building obstacle in relationship with the BIPV in terms of compass direction. The complexity of BIPV and surrounding placement manifestly brings difficulties for designers and planners to build an optimal solution when intending to achieve the best techno-economic targets (Kanters \& Wall, 2014; Kanters, 2015; Ning, et al., 2017).

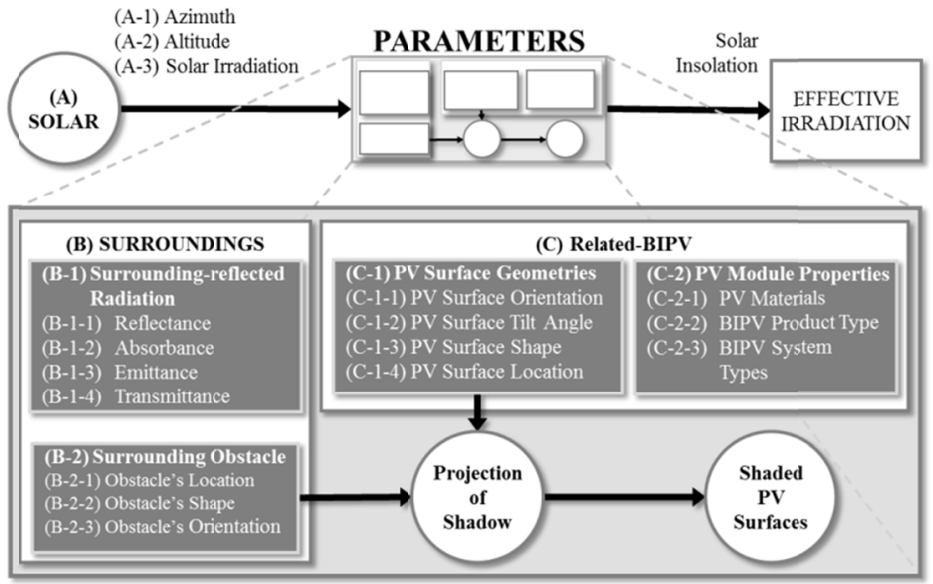

Figure 4. Relationship among parameters of partial shading effects influencing solar insolation of PV surfaces

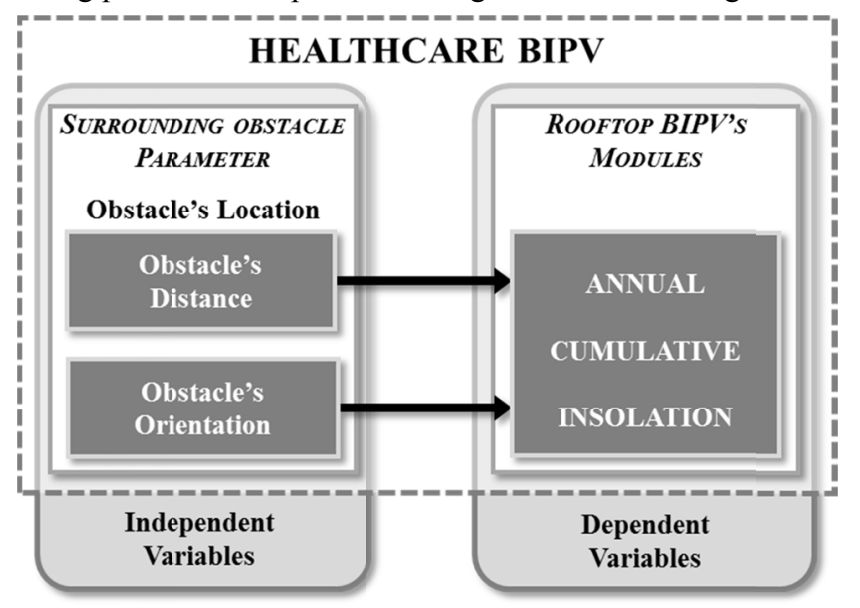

Figure 5. Conceptual framework of the study

Hence, this leads to the research question: of how the distance between building obstacle and BIPV, the orientation of 
BIPV and the orientation between building obstacle and BIPV affect the potential to generate power of a BIPV. This study furtherly hypothesized that is orientation has more impact on the annual cumulative insolation on PV surfaces than distance. Thus, the conceptual framework of the study can be established and illustrated in Figure 5.

\section{Methodology}

\subsection{Related Techniques in building performance simulation of BIPV}

\subsubsection{BIPV and Building Performance Simulation (BPS)}

Though BIPV technology has great potential for reducing carbon emissions from building energy consumption. However, there are currently some obstacles in the general adoption of this technology. One of the obstacles is evidence-based design that needed on the effectiveness of the maximum-efficient design of BIPV buildings as well as the benefits of BIPV to convince owners to opt for BIPV buildings (Kuo, Hsieh, Guo, \& Chan, 2016). In order to quantify the benefit of BIPV design, it is required to estimate the potentials of the BIPV electricity production first by quantitative assessment of irradiance on the required surfaces to install PV modules by using Building Performance Simulation (BPS) tools. The main purpose of Building Performance Simulation (BPS) is to quantitatively justify design decisions as a result of predicting real physical conditions in a building by using a computational model, and to support building design processes by providing a high integrity representation of the dynamic, connected and non-linear physical processes that govern the disparate performance aspects that dictate overall acceptability of building and their related energy supply systems, particularly, the BPS involves a scientific basis in its simulation algorithms and the level of building information detail required as input data (Bazjanac, et al., 2011; Hitchcock \& Wong, 2011; Clarke \& Hensen, 2015; Shen \& Lu, 2016). PV simulation tools are useful to perform detailed analysis of system performance and assess the viability of a PV system in terms of energy production (Eltawil \& Zhao, 2010). For the purpose of optimal PV system design, many models and studies have been proposed in literature (Ning, et al., 2017) ranging from the solar radiation model (Liu \& Jordan, 1960; Goswami, Kreith, \& Kreider, 2000), PV panel conversion model for unshaded PV (Clark, Klein, \& Beckman, 1984; Goss, Cole, Betts, \& Gottschalg, 2014; Ramli, Twaha, Ishaque, \& Al-Turki, 2017), the power mismatch models for the partially shaded PV systems (Alonso-Garcia, Ruiz, \& Hermann, 2006; Karatepe, Boztepe, \& Çolak, 2007; Dolara, Lazaroiu, Leva, \& Manzolini, 2013; Bai, et al., 2015) and to evaluating and optimizing the efficiency of PV systems working in partial shading conditions (Woyte, Nijs, \& Belmans, 2003; Celik, Karatepe, Gokman, \& Silvestre, 2013; Celik, Karatepe, Silvestre, Gokman, \& Chouder, 2015; Ning, et al., 2017). However, these research results have not been commonly used in practical design practices yet, and have mainly been limited in a few academic research studies. One of the major barriers, it is argued, lies in the complexities in accessing or reconstructing a large number of related information, especially building's information as it varies in locations, shapes and obstacles (Asl, Zarrinmehr, Bergin, \& Yan, 2015; Ning, et al., 2017). The current practice involves collecting the mentioned information from a variety of sources and manually transforming this information into the specific input required by performance simulation (Gupta, Cemesova, Hopfe, Rezgui, \& Sweet, 2014). While based on professional expertise, this manual process tends to be uniquely performed by each practitioner according to methods, arbitrary judgements, rules-of-thumb developed over time by that individual. The results is a non-standardized process that produces energy models that can widely vary from one modeler to the next, even given the same initial building design information and these BPS models have been achieved with much duplication of efforts, time-consuming, and significant deficiencies remain. This is applicable not only to various BPS tools but also to various renewable energy simulation tools including solar PV simulation models as well (Bazjanac, et al., 2011; Hitchcock \& Wong, 2011; Clarke \& Hensen, 2015; Ning, et al., 2017).

\subsubsection{Automated BPS and Building Information Modeling (BIM)}

An intelligent approach to better deal with these deficiencies in BPS, from the time-consuming, cumbersome and error-prone of manual data generation and use of improvised defined data that may invalidate the results, is the automation of BPS input data acquisition and transformation, it has been a goal of the buildings industry for decades (Bazjanac, et al., 2011; Hitchcock \& Wong, 2011; Clarke \& Hensen, 2015) Reusing of existing data by interoperable processes would significantly reduce the time and overhead associated with the creation of simulation models (Hand, Crawley, Donn, \& Lawrie, 2005; Bazjanac, et al., 2011; O'Donnell, et al., 2011). An interoperable, intelligent and object-oriented simulation model would enable bi-directional data exchange with a Building Information Modelling (BIM) authoring applications, reusing of geometric and other data from different models significantly reduces the overhead associated with the definition of input data and has the potential to eliminate error-prone manual processes (O'Donnell, et al., 2011; Ning, et al., 2017).

Nowadays, it is generally accepted by the Architecture, Engineering, Construction, and Operations (AECO) industries that Building Information Modeling (BIM) is the most promising technology for enhancing the performance and quality of construction (Kuo, Hsieh, Guo, \& Chan, 2016; Somboonwit, Boontore, \& Rugwongwan, 2017). A BIM is a tool / methodology / paradigm / process of virtual design and construction involving the generation and management of digital representations of physical and functional characteristics of a facility which creates and uses the coordinated, consistent, computable information of the $3 \mathrm{D}$ models of the project components interconnect with the holistic information that conceived as a source of shared knowledge to support decision-making, through the life cycle of the building. When completed, these computer-generated-semantic-3D models contain precise geometry and data needed 
to support the construction, fabrication, and procurement activities through which the building is realized (Krygiel \& Nies, 2008; Kymmell, 2008; Eastman, Teicholz, Sacks, \& Liston, 2011; Matthew, Jason, Melissa, Seokho, \& Fiona, 2013; Ladenhauf, et al., 2015; Agugiaro, 2016; Kuo, Hsieh, Guo, \& Chan, 2016; Somboonwit, Boontore, \& Rugwongwan, 2017). There is a very useful feature of BIM is that building geometry can be extracted from a BIM model to support the assessment of alternative sustainable design principles.

BIPV design processes involve elements of expertise deriving from multiple disciplines such as architects, civil, mechanical and electrical engineers (Negendahl, 2015). With numerous unified tools that act both as a design tool and BPS tool exist, building designers still seem to prefer to crate and explore design options in dedicated design tool such as AutoCAD, ArchiCAD, Revit, SketchUp, etc., as they support the concept of a sketch and the freedoms associated with design tools. The integration of a design tool and a BPS tools is fundamentally changing building design into a faster, performance-aware and more flexible process, which eases the production of multiple design alternatives that provide model foundations for BIPV design optimization (Negendahl, 2015; Ning, et al., 2017). Furthermore, many buildings have already been modelled with BIM authoring tools, in which the features of most building components, e.g. shape, size, materials, locations as well as building's environment, has been accurately described (Ning, et al., 2017).

Regarding reviews of BIM-based simulation and optimization for BIPV, there are several types of study related to this research scope including researches focus on BIPV simulation (Long, Wang, Zhou, \& Zhang, 2014; Chen \& Ger, 2014; Dixit \& Yan, 2015), BIPV optimization (Welle, Haymaker, \& Rogers, 2011; Ning, et al., 2017) and BIPV integrated parametric design (Kensek, 2014; Kim, Asl, \& Yan, 2015, Hofer, Groenewolt, Jayathissa, Nagy, \& Schlueter, 2016; Nagy, et al., 2016; Somboonwit, Boontore, \& Rugwongwan, 2017). Unfortunately, only a small fraction of BPS tools can be used in automated processes required to perform BIPV performance simulation and optimization, and it is unable to be successfully achieved because commercially available tools offer simulation of particular performances to some extent, and yet there is still no 3D CAD/BIM commercial tool that targets all types of BIPV (not only roof mounted), nor complex BIPV or provides seamless model exchange and full geometrical representation for integration in architectural design (Attia, De Herde, Gratia, \& Hensen, 2013; Negendahl, 2015; Jakica, 2017; Somboonwit, Boontore, \& Rugwongwan, 2017).

\subsubsection{Simulation of Partial Shading Effects}

It is important to include an accurate methodology for evaluating the fluctuation of potential PV power generation caused by partial shadow effects. Therefore the quantitative assessment of the incident irradiance on their surface is the most important issue, which affects the performance of the PV systems directly (Yoon, Song, \& Lee, 2011; Celik, Karatepe, Gokman, \& Silvestre, 2013; Yang, 2015). There are several studies that provide theoretical models to simulate the behavior of PV modules and generators in conditions of non-uniform radiation and also studies that provide models to estimate the effective irradiation, thus, after incorporating shading effects and these models are able to be used to estimate the electricity losses and mismatch losses in which the PV system incurs due to the effect of inhomogeneous irradiation (Norton, et al., 2011; Alam, Coors, Zlatanova, \& Oosterom, 2012; Celik, Karatepe, Gokman, \& Silvestre, 2013; Masa-bote \& Caamaño-Martín, 2014; Celik, Karatepe, Silvestre, Gokman, \& Chouder, 2015; Hong, Lee, Koo, Jeong, \& Kim, 2017; Zomer \& Rüther, 2017). However, there are a very few studies of the optimization of facility planning and buildings placement that strengthen solar energy utilization of a building in an interconnected composition with surrounding buildings to reduce the impacts of shading conditions due to dynamic changing of solar geometry. Kanters and Wall (2014) explored the effect of four factors on the solar potential of building blocks typically used in urban planning, i.e. form, density, orientation and roof type. The results showed that density (the closer the distance between buildings is, the higher the urban density becomes) was the most influential factor, while the effect of orientation was not that clear (Kanters \& Wall, 2014). Bhattacharjee, Noble, Kensek and Schiler (2016) studied solar envelope for sites with existing buildings using a computational design tool for generating solar envelopes that allowed additional volume to be added to existing building geometry without further casting shadows on neighboring sites. While the usable floor area has been increased but the shape of the buildings has been transformed into something that irregular and eccentric, furthermore, if the physical boundaries of the site and the surroundings the determine the solar envelope of the buildings have been changed, it possibly that the added volume might not be positively contented complying with the change of solar envelope. Thus, it possibly implies that focusing on the shape of surrounding obstacles to enhance solar energy utilization might be an endless task (Bhattacharjee, Noble, Kensek, \& Schiler, 2016). In high-density urban areas or campuses, the solar access of a building has been affected directly, especially the clustered facility developments that put pressures on land usage and create large buildings occupying maximum plot ratio that create solar obstructions on rooftop PV systems that installed on lower-rise buildings, as shown in Figure 6.

Without proper siting and buildings placement, a structure cannot be designed for maximum power generation from a solar PV system. Referring to a previously mentioned argument, there are just a few studies of the investigation of the parameter of surrounding obstacles but there is no previous study that explores the most critical parameters of surrounding obstacle determining the projection of shadow on PV surfaces that influence over the potential to power generation of a PV system through automated processes of BPS and BIM. The findings of the study are important for decision supporting in BIPV design and facility planning and providing guidelines of automated BPS processes that 
seamlessly interoperating with BIM.

\subsection{Case Study}

This study presents an analytical method to explore the most critical parameters of the partial shading effects on PV surfaces caused by surrounding obstacles_obstacle's distance and obstacle's orientation, that affect the annual cumulative insolation on photovoltaic modules that are attached to roof surfaces through an automatic collaboration of a BIM authoring software, Autodesk Revit, and a cloud-based building performance analysis tool that embedded within a BIM authoring software, Autodesk Insight 360.

\subsubsection{Generalizable Building Designs (GBDs)}

Thailand has a multilevel healthcare system aiming to improve geographical access of the population, in addition to enhancing system efficiency through rational use of service by level and proper referral systems (Jongudomsuk, et al., 2015). Public healthcare facilities in Thailand have provided medical services with interrelationships between buildings that contain sections / departments / units and environment. Most of their design and construction have been under supervision of the Design and Construction Division (DCD), a subdivision of the Ministry of Public Health (MOPH), Thailand. There is more than fifty years that the DCD has produced and provided more than 10,000 designs of healthcare facilities. In general, the process of public healthcare facilities planning is developed by a multidisciplinary team including architects, engineers, and interior designers who work for the DCD and medical specialists. Most of the public healthcare facilities have been administered by the using of DCD's Generalizable Building Designs (GBDs), i.e. cookie-cutter healthcare building designs, from the concept of "one size fits all" for universal application on healthcare facilities design which is in the GBD criteria of its type, functions, size and work load capacity.

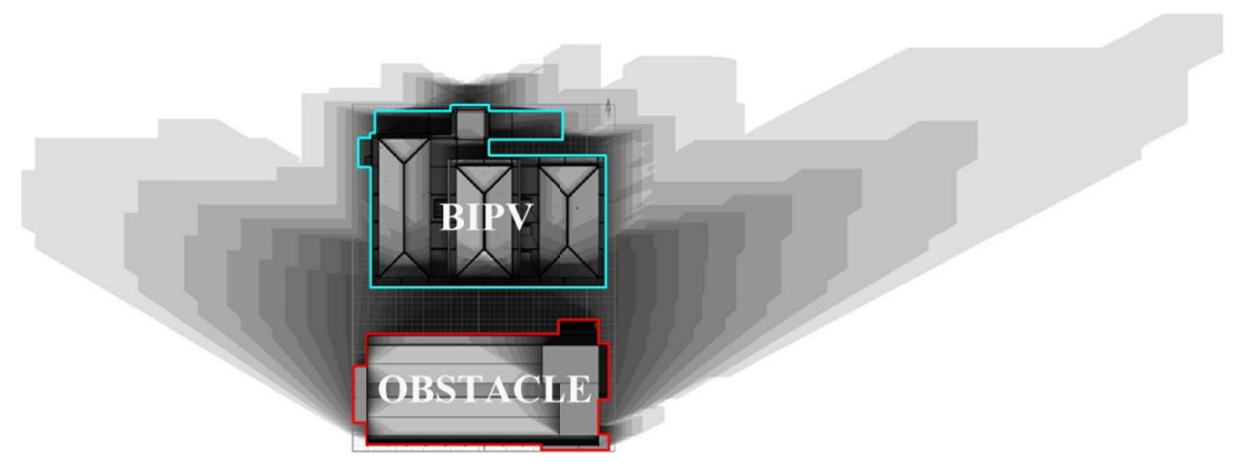

Figure 6. An illustration of a shadow range from 8.00 am to $5.00 \mathrm{pm}$ on winter solstice, demonstrates a common problem that PV system designers may encounter to optimize the rooftop PV system deployment.

The GBDs have been developed with the aims to minimize time and resources consumed during new building design processes and to be flexible to accommodate the healthcare construction projects all over Thailand, especially in the rural and remote areas. It is inevitable that the GBDs should be simple and easy to be built by any local contractors which most of them are using low construction technology and capable to acquire just inexpensive and locally available materials. However the GBDs have been utilized without or lack of decisive thoughtfulness on local factors, i.e., location, orientation, weather condition and particularly, inept configuration of the site planning to minimize energy consumption and enhancing renewable energy generation (Somboonwit, 2011; Somboonwit \& Sahachaisaeree, 2012).

Public healthcare facilities in Thailand usually located and built in government-own or donated lands, thus these parcels of land are all different sizes and shapes, furthermore, their orientations and surrounding contexts are uncontrollable. The MOPH is obliged to build public healthcare facilities on these sites whenever their sizes could fit all the buildings and facilities that needed.

Two case study buildings have been selected: (1) an outpatient department (OPD) building, DCD number 3130/2536, was chosen as a case study to be the BIPV which PV modules have been installed on the OPD's sloped roofs, and (2) a ward building, DCD number 8605 was chosen as a case study to be the obstacle. These two buildings are the widely established in the community/general hospitals that provide secondary level of Thailand's healthcare services that serves more than 20 million of Thai people (Somboonwit \& Sahachaisaeree, 2012). The OPD building usually located on a hospital's site as the main building and a critical gateway for the healthcare facilities. The OPD building has been selected to be the BIPV because it is the principal GBD for this level of healthcare service and it has the highest ratio of roof-to-functional-area among all the GBDs and its roofs are able to contribute a large amount of solar irradiation since that the contribution of façades is rather limited and they receive less irradiation than the roof, also have a limited contribution in solar energy production (Kanters, 2015). The minimum distance that is a separation between buildings in healthcare facilities must be at least 6 meters, from the outermost edge of a building to the outermost edge of another building, with vertical clearance which is unobstructed vertical passage space that required along the buildings 
for fire safety and circulation routes.

\subsubsection{Physical Settings of the Case Study}

The physical settings of the two case study buildings are those of typical cost-control public health facilities: the structural construction is in situ reinforced concrete, the exterior opaque walls are plastered brick walls, the glazing for windows is 6-millimeter clear float glass, and the roofs are fiber-cement roof tiles.

The case study building \#1, an OPD building number 3130/2536 as shown in Figure 7(a), this two-story building has an irregular-shaped footprint with gross floor area of $1,125 \mathrm{~m}^{2}$ which contains functional areas to be fully operational Out-patient Department: examination rooms, an emergency department, a laboratory, an x-ray room, a dental department, a pharmacy department, operation rooms, and an administration department. It is a mixed-mode building that combines natural and mechanical systems for ventilation and cooling. The sloped roofs of the OPD building are three rectangle-based hipped roofs with $20^{\circ}$ roofs' pitches. The total area of the sloped roof surfaces is $712 \mathrm{~m}^{2}$, these surfaces of these roofing systems have been used to mount PV modules and the total cumulative solar insolation on these surfaces of the solar PV modules has been taken into account for estimating solar potential and output energy of the PV systems. The height from the ground level to the highest point of roofs is approximately 10 meter.

The case study building \#2 is a ward building, DCD number 8605 as shown in Figure 7(b). This five-story rectangle shaped building is 21.00 meters wide, 46.50 meters long and 24.00 meters high. This ward building has usually been placed nearby the OPD building, the minimum distance equals to 6 meters without the maximum distance, depends on the site but does usually not exceed 36 meters.

\subsection{Steps of Automated BPS}

In this study, the axis of the OPD building has been aligned with the axis of the ward building, center to center of the two buildings. These aligned axes which are the representation of the interaction between geometries of the two buildings is kept stationary to maintain the consistency of the simulations while comparing the annual cumulative insolation of the 8-different orientations of the axis-aligned buildings and the 43-different distances between the two buildings.

\subsubsection{BIM Models Developing and the LOD}

The proposed methodology has three main steps. The first step, BIM models of the two case study buildings have been developed. BIM model of the case study building \#1, OPD building, has been developed at LOD 300.

LOD (Level of Development) is concept to describe information richness of BIM objects, ranges from LOD 100 (basic/conceptual) to 500 (highly detailed/precise). LOD 300 is the Model Elements is graphically represented within the model as a specific system, and non-graphic information may also be attached to the Model Element (BIMForum, 2013; Volk, Stengel, \& Schultmann, 2014; Autodesk Sustainability Workshop, 2017).

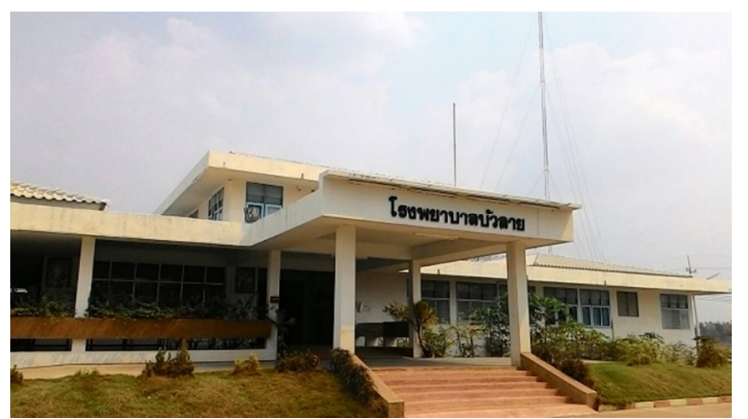

(a)

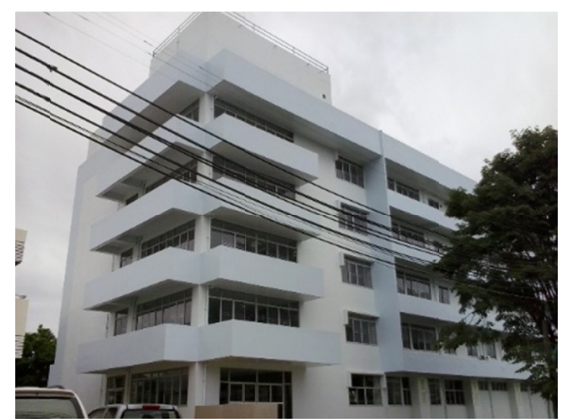

(b)

Figure 7. Photographs of (a) the OPD building and (b) the wards building

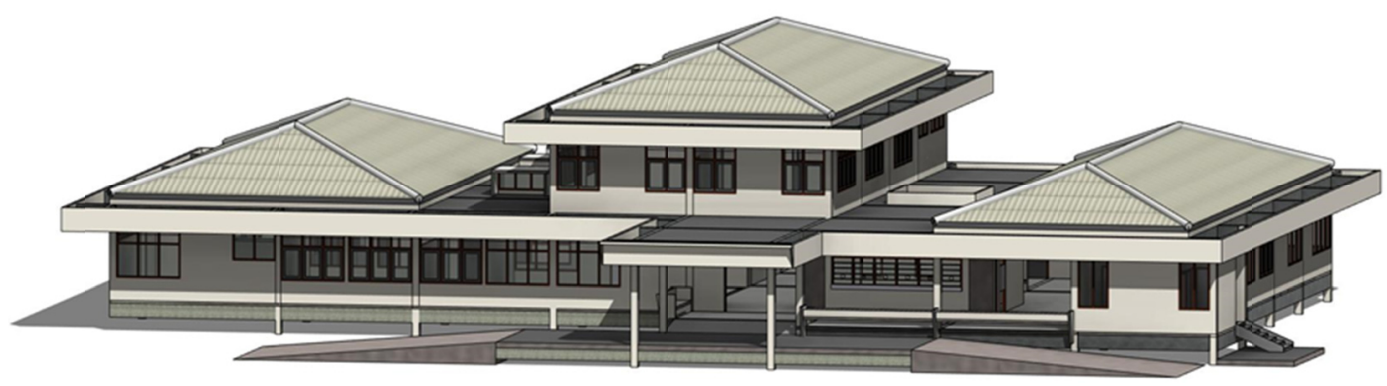

Figure 8. The LOD-300 BIM model of the OPD building - the BIPV 


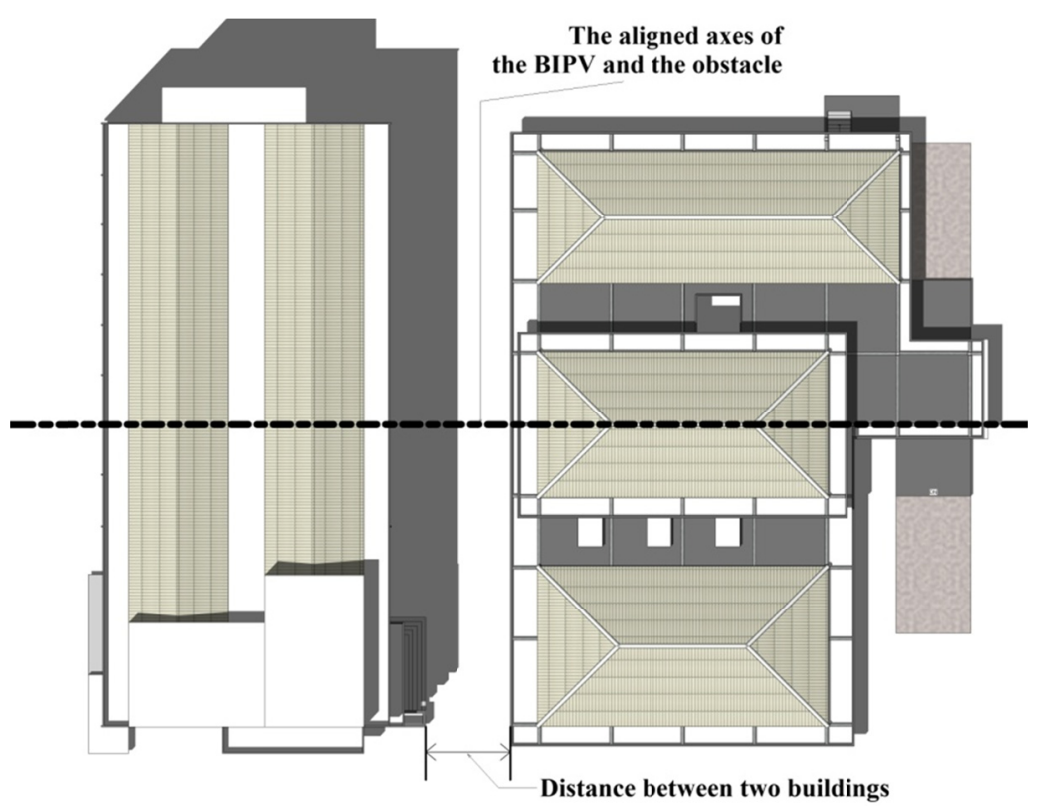

Figure 9. Illustration of the aligned axes of the BIPV and the obstacle and distance between the buildings

The OPD has been chosen to be a BIPV, thus a development of its BIM model requires details and functionalities with a certain accuracy, information richness and actuality of the underlying data to support further design and modeling processes of PV systems (Figure 8). Otherwise, the development of the ward building's BIM model is at LOD 200, it is graphically represented within the model as a generic system, non-graphic information may also be attached to the Model Element (BIMForum, 2013). This case study \#2 has been utilized to be a building-surrounded obstacle, thus, its important BIM parameters are the obstacle's location and geometry that have been derived into three-dimensional coordinates that used to determine the projection of shadow on PV modules by the dynamic change of solar azimuth and altitude angles.

That is very important to limit the LOD of the model to the minimum, due to more-detailed modeling needs more time and effort that ranging from doubling the effort to eleven folding them, and more computational power of the building performance simulation to acquire the results is also needed (Leite, Akcamete, Akinci, Atasoy, \& Kiziltas, 2011).

\subsubsection{Location Settings}

The second step is setting a BIM project to create a digital environment for solar insolation simulation. Import the two BIM models into a BIM project and align the center axes of the models as shown in Figure 9. Set the orientation of the axis-aligned models to face south: true north-based azimuth (AZ) of $180^{\circ}$, the baseline models which have $0^{\circ} \mathrm{CW}$ (Clockwise) rotation angle. The nearest distance between the two models has been set to 6 meters. The location to simulate the annual cumulative insolation is Bangkok, Thailand. Its global coordinates are $13^{\circ} \mathrm{N} 100^{\circ} 30^{\prime} \mathrm{E}$ and this location lies two meters above sea level. The monthly mean assess global solar radiation (GSR) of Bangkok has been estimated in the range of 5.64 to $22.53 \mathrm{MJ} / \mathrm{m}^{2} /$ day (Waewsak, Chancham, Mani, \& Gagnon, 2014), it is equal to 1.57 to $6.26 \mathrm{kWh} / \mathrm{m}^{2} /$ day or 573.05 to $2,284.9 \mathrm{kWh} / \mathrm{m}^{2} /$ year.

\subsubsection{Obstacle's Distance and Obstacle's Orientation}

The third step is to simulate the annual cumulative insolation on the PV surfaces of the BIM model of the OPD building using Autodesk Insight 360, a fully automatic cloud-based building performance analysis tool. To discover the influence of obstacle's distance, the baseline models $-0^{\circ} \mathrm{CW}$, has been performed annual cumulative insolation simulation at every 1-meter interval of the distance from 6 meters to 48 meters between the axis-aligned case study buildings. There are 43 simulations have been performed at $0^{\circ} \mathrm{CW}$ models. To discover the comparative influence of obstacle's distance and obstacle's orientation, annual cumulative insolation simulations of $0^{\circ} \mathrm{CW}$ have been performed against other seven orientations clockwise $(\mathrm{CW})$, i.e. $45^{\circ}\left(\mathrm{AZ}=225^{\circ}\right), 90^{\circ}\left(\mathrm{AZ}=270^{\circ}\right), 135^{\circ}\left(\mathrm{AZ}=315^{\circ}\right), 180^{\circ}(\mathrm{AZ}$ $\left.=0^{\circ}\right), 225^{\circ}\left(\mathrm{AZ}=45^{\circ}\right), 270^{\circ}\left(\mathrm{AZ}=90^{\circ}\right)$ and $315^{\circ}\left(\mathrm{AZ}=135^{\circ}\right)$, as shown in Figure 10 . Annual cumulative insolation of all seven other orientations have been simulated at every 1 meter intervals of the distance from 6 meters to 48 meters between the axis-aligned buildings as well. There are total 344 annual cumulative insolation simulations have been performed in this study.

The mentioned methods of modeling and simulation can be extended for annual PV energy production simulations according to the capabilities of the analysis tool (Egger, 2015; Stine, 2015).

\section{Results and Discussion}

Once a simulation has been performed, the results have been displayed automatically within the BIM authoring platform. Individually, each of the simulations provides results of solar analysis including; total cumulative insolation 
$(\mathrm{kWh})$, cumulative insolation per square meter $\left(\mathrm{kWh} / \mathrm{m}^{2}\right)$, total simulated area $\left(\mathrm{m}^{2}\right)$ and the interval of total time period of the analysis, month-day to month-day, and the intervals of time periods during the daily analysis, sunrise to sunset, as shown in Figure 11(a). The analysis tool also provides graphical results within the BIM models as shown in Figure 11(b). Insolation refers to the quantity of solar radiation energy received on a surface of size one $\mathrm{m}^{2}$ during an amount of time. It is commonly expressed as average irradiance in watts per square meter $\left(\mathrm{W} / \mathrm{m}^{2}\right)$ or kilowatt-hours per square meter per day $\left(\mathrm{kW} \bullet \mathrm{h} /\left(\mathrm{m}^{2} \bullet\right.\right.$ day $\left.)\right)$ (or hours/day) (Solarinsolation.org, 2012; Sinovoltaics, 2014).
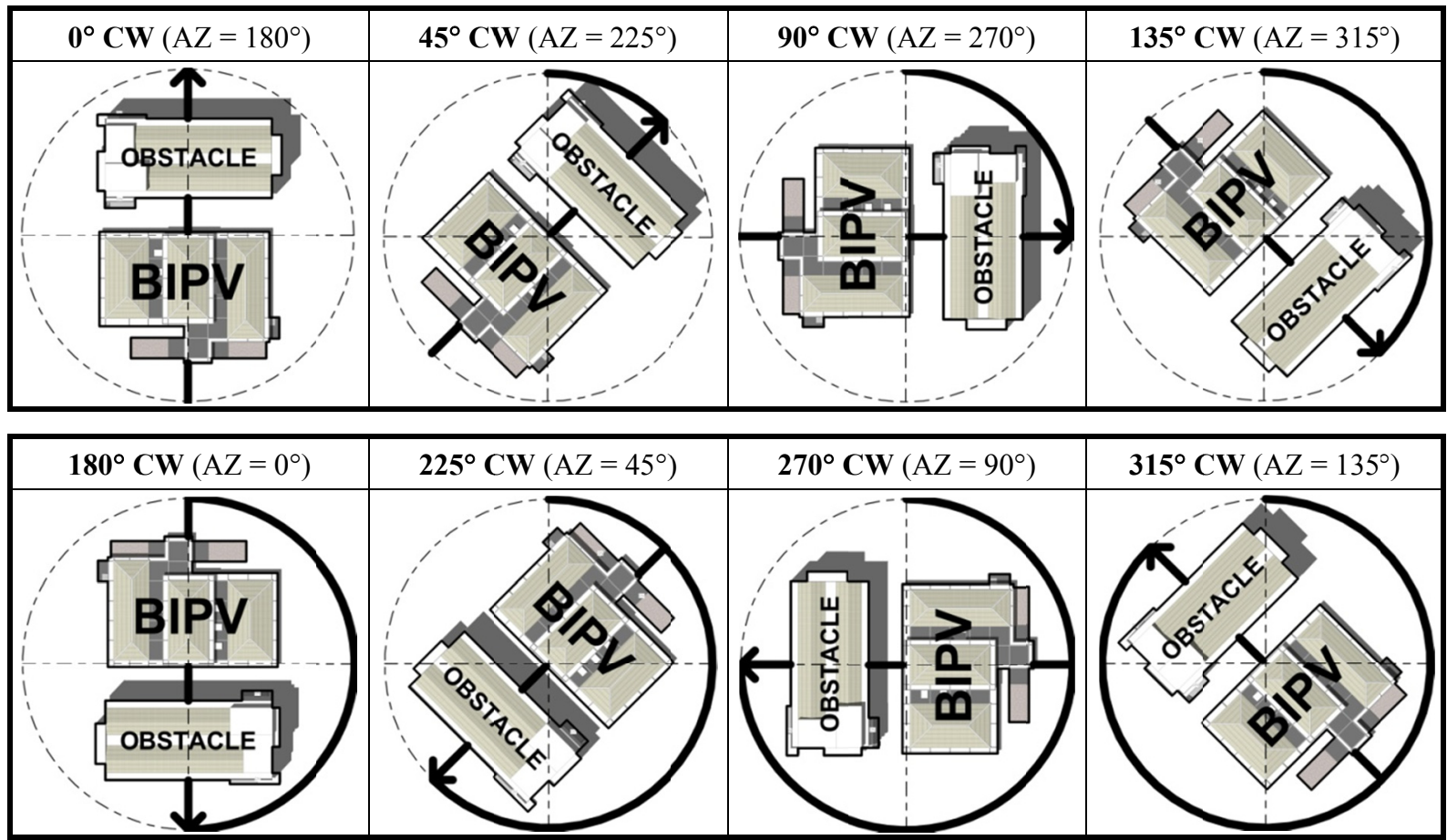

Figure 10. Orientations of the case study - the axis-aligned buildings

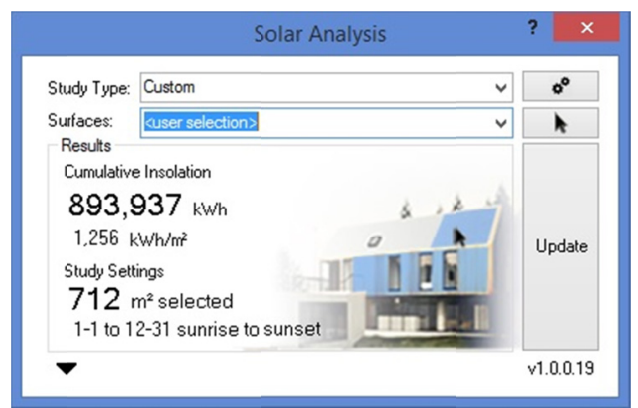

(a)

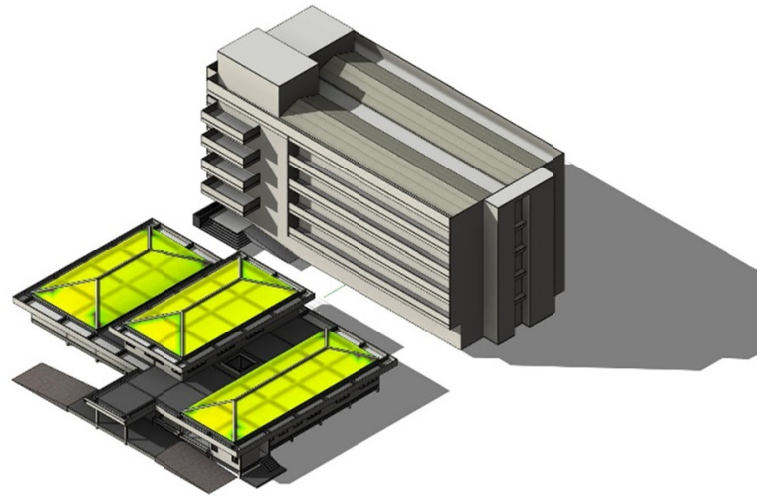

(b)

Figure 11. (a) Solar Analysis results of the $0^{\circ} \mathrm{CW}$ at 6-meter distance (b) gradient colors of the ranges between the minimum cumulative insolation (purple) and the maximum (bright green) on the analyzed surfaces

\subsection{Comparisons of the Annual Cumulative Insolation of All Simulations}

As outlined, the case study carried out with 344 combinations of 8 orientations and 43 intervals of 1-meter distance; from 6 to 48 meters, have been simulated to explore the comparative effects between obstacle's distance and obstacle's orientation parameters that cause partially shading effects and influence the potential solar power generation of a photovoltaic (PV) system. The annual cumulative insolation on the PV surfaces of all simulations has been presented in Figure 12. The simulation results of every orientations have shared just one thing in common, their curves are logarithmic shape that have periods of rapid increase at first, followed by periods where the gains increasing slowly then reach the plateaus at their farthest distances. It can be seen that it is a distinctive difference to separate the 8 curves into three groups: the first group $\left(\mathrm{A}_{1}\right)$ is only $0^{\circ} \mathrm{CW}$ orientation, the curve that starts at the highest annual cumulative insolation and increases at very slow rate while distance is increasing; the second group $\left(\mathrm{A}_{2}\right)$ consists of curves that start at slightly lower annual cumulative insolation than $\mathrm{A}_{1}$ but increase at faster rate while distance is increasing than $\mathrm{A}_{1}$, the curves in the $\mathrm{A}_{2}$ are $45^{\circ} \mathrm{CW}, 180^{\circ} \mathrm{CW}$ and $315^{\circ} \mathrm{CW}$ orientation (Figure 13); and the third group 
(B) that start at lower annual cumulative insolation than both $\mathrm{A}_{1}$ and $\mathrm{A}_{2}$ but increase at much faster rate, it consists of $90^{\circ} \mathrm{CW}, 135^{\circ} \mathrm{CW}, 225^{\circ} \mathrm{CW}$ and $270^{\circ} \mathrm{CW}$ orientation, as shown in Figure 14.

Figure 13 shows the only curve of the first group $\left(\mathrm{A}_{1}\right)$ that has the maximum annual cumulative insolation on the PV surfaces at the nearest distance, 6 meters, is $0^{\circ} \mathrm{CW}$ orientation $(893,937 \mathrm{kWh})$ and it keeps being the maximum until it passes 15 meters. Each of a more 1 -meter interval, the $0^{\circ} \mathrm{CW}$ gains more annual cumulative insolation very slowly. The shape of the curve of the $0^{\circ} \mathrm{CW}$ is almost linear and it has been least influenced by distance of all. While curves in the second group $\left(\mathrm{A}_{2}\right)$ show that $45^{\circ} \mathrm{CW}, 180^{\circ} \mathrm{CW}$ and $315^{\circ} \mathrm{CW}$ orientation that have the annual cumulative insolation on the PV surfaces lower than the $\mathrm{A}_{1}$ at 6-meters distance but they have raised fast in annual cumulative insolation until all curves of $A_{2}$ surpass $A_{1}$ at 16 meters. Figure 14 shows a rally of the fast-rising curves in the third group (B); $90^{\circ} \mathrm{CW}, 135^{\circ} \mathrm{CW}, 225^{\circ} \mathrm{CW}$. The biggest gain is $270^{\circ} \mathrm{CW}$ orientation that has truly come from behind, from the lowest annual cumulative insolation at 6-meter distance becomes the highest at 45 meters to 48 meters-the farthest distance of the study.

At the distance of 6 meters, the compared potential solar power between $0^{\circ} \mathrm{CW}\left(\mathrm{A}_{1}\right)$ and $270^{\circ} \mathrm{CW}(\mathrm{B})$ is different dramatically, it is $43,411 \mathrm{kWh}$ or $5.1040 \%$ that $0^{\circ} \mathrm{CW}$ higher than $270^{\circ} \mathrm{CW}$. Contrastively, at the distance of 48 meters, $0^{\circ} \mathrm{CW}$ obtains the annual cumulative insolation less than $270^{\circ} \mathrm{CW}$ does for $0.6277 \%$, additionally, at this distance of $0^{\circ} \mathrm{CW}$, it gains more annual cumulative insolation than it does at the 6-meter distance just $0.93 \%$. In spite of the fact that at 48 meters of $270^{\circ} \mathrm{CW}$ obtains annual cumulative insolation more than its 6-meter distance does tremendously, $6.7501 \%$, but there would be very few hospitals and not practical that an OPD building has been located that far from a wards building just for serving the purpose of solar energy generation.

\subsection{The comparison of influence between obstacle's distance and obstacle's orientation}

As previously mentioned that the sizes, shapes, orientations and surrounding contexts of the sites to establish public healthcare facilities in Thailand are uncontrollable, furthermore, the obligation to use DCD's Generalizable Building Designs (GBDs) to be constructed in these healthcare facilities have exacerbated the problems of nonoptimal PV system installations caused by partial shading effects. The PV modules attached sloped roofs have also been a problem, especial PV hipped roofs, they are unable to generate the highest energy production because of their surfaces would never have the optimal inclination and orientation to receive the highest solar radiation constantly and simultaneously. These limitations must be brought to be carefully considered during the PV system design processes.

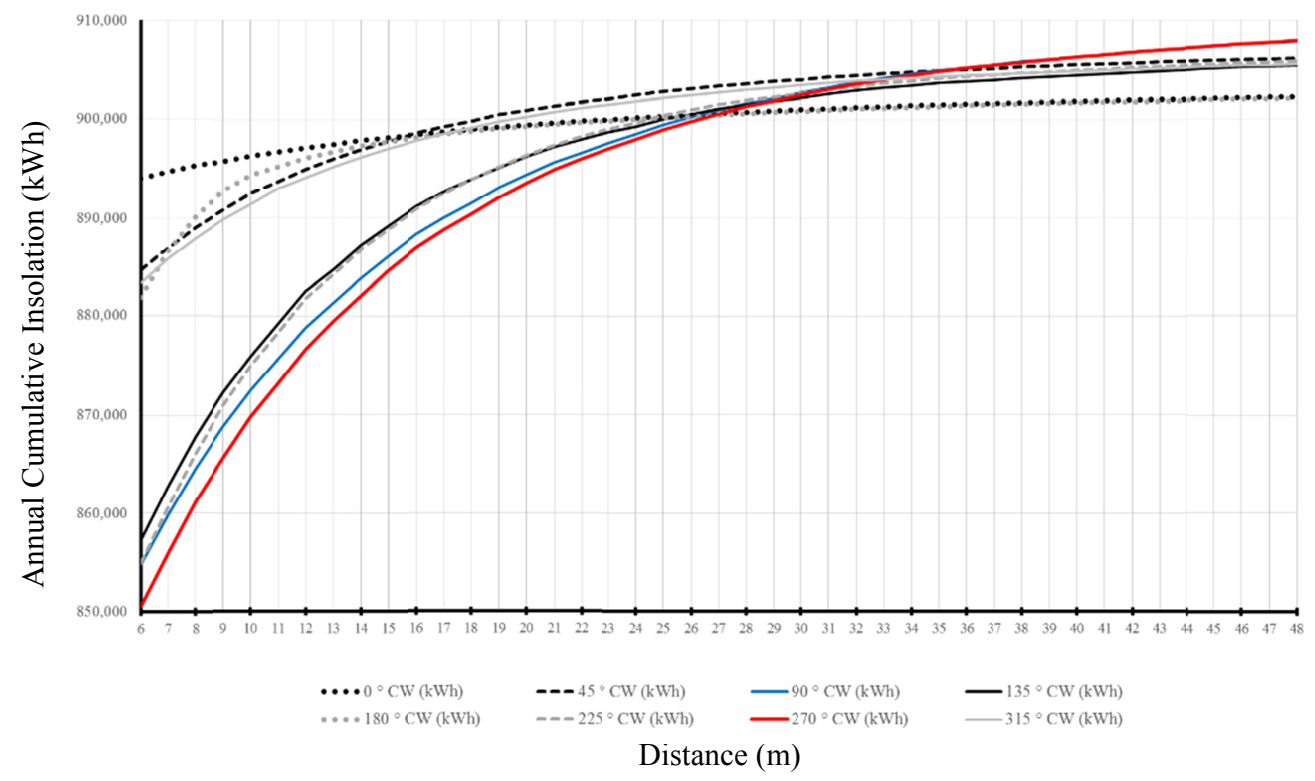

Figure 12. Annual cumulative insolation of all orientations and distance; 8 orientations, 43 distances from 6 meters to 48 meters

Results from this study show that obstacle's orientation and obstacle's distance of a building-surrounded obstacle are both important parameters that influencing the annual cumulative insolation of PV surfaces but in the different contexts. It was also shown that at such orientations of the first group $\left(\mathrm{A}_{1}\right): 0^{\circ} \mathrm{CW}$ and the second group $\left(\mathrm{A}_{2}\right): 45^{\circ} \mathrm{CW}$, $180^{\circ} \mathrm{CW}$ and $315^{\circ} \mathrm{CW}$ orientation, the potential PV power generation of the BIPV is high since the nearest distance and almost consistent until the farthest distance between the BIPV and the obstacle. These $\left(\mathrm{A}_{1}\right.$ and $\left.\mathrm{A}_{2}\right)$ are the recommended orientations for BIPV application on lower-rise buildings in urban environments, such as healthcare facilities, as they steadily receive solar irradiation with less sensitive to a crucial parameter of surrounding obstacles - the obstacle's distance, that means the lower-rise BIPVs with these orientations are capable of generating solar energy to reach their nearly full potential, whether how far they are from a much-taller surrounding obstacle. On 
the other hand, there is obviously seen that the distance between BIPV and surrounding obstacle is also a very powerful parameter that influences the potential PV power generation, thus on the condition of the placement that define orientation of the BIPV and a surrounding obstacle is not optimal, such as $90^{\circ} \mathrm{CW}, 135^{\circ} \mathrm{CW}, 225^{\circ} \mathrm{CW}$ and $270^{\circ} \mathrm{CW}$ orientation, placing the two buildings farther from each other will enhance the energy producing from the PV system.

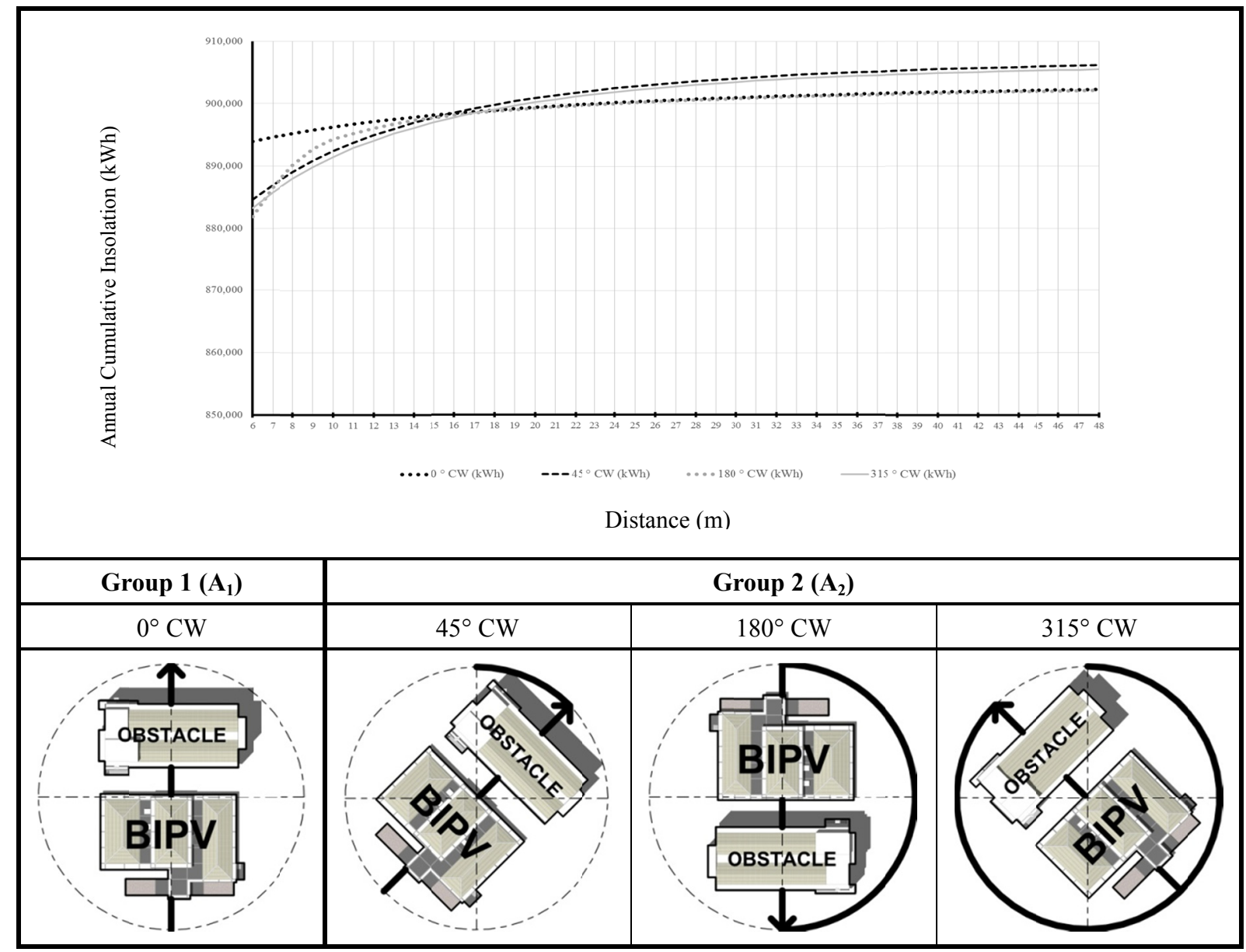

Figure 13. Annual cumulative insolation of Group $1\left(\mathrm{~A}_{1}\right)$ and Group $2\left(\mathrm{~A}_{2}\right)$

\section{Conclusion and Future Work}

This study presents an analytical method to explore the comparative effects between the most critical parameters of a surrounding obstacle that cause partial shading effects; obstacle's distance and obstacle's orientation that influence the potential solar power generation of a rooftop PV system.

The proposed methodology is based on the simulated annual cumulative insolation obtained from rooftop PV surfaces of eight different orientations and forty-three different distances between the BIPV and building obstacle through an automatic collaboration of a BIM authoring software, Autodesk Revit and a cloud-based building performance analysis tool, Autodesk Insight 360. In this study, two GBDs has been selected to be the case studies; an OPD building for the BIPV and a wards building for the obstacle. BIM models of the two case study buildings have been built at different LODs (Level of Development) to provide a suitable level of details and functionalities with a certain accuracy, information richness and actuality of the underlying data while maintaining the simplicity of computational processes. The BIM-based automated simulations have been substantiated the usability of one of the most promising technology in AECO industry that removed the deficiencies; time-consuming, cumbersome and error-prone of the non-automated processes. This study explores that orientation and distance of a surrounding obstacle are both crucial parameters that dramatically affect the annual cumulative insolation of PV surfaces. The findings of this study also support decision making for BIPV designers and facility planners to acknowledge which the BIPV and the obstacle placement is highly effective and a worthwhile investment to install a PV system, and which one is encountering a problem and how to solve it. Solar power is expensive and inefficient, thus a well-integrated solar system might require extra efforts and considerations of design work, especially the architectonical integration of PV elements into the urban environments to capture the maximum amount of solar radiation. For future work, parametric design and modeling tools that enable parameters to be processed by mathematical formulas and computational algorithms can be integrated with the BIPV design to suggest a systematic design decision process that might help maximizing the efficiency and productivity of PV implementations in dense urban environments. 


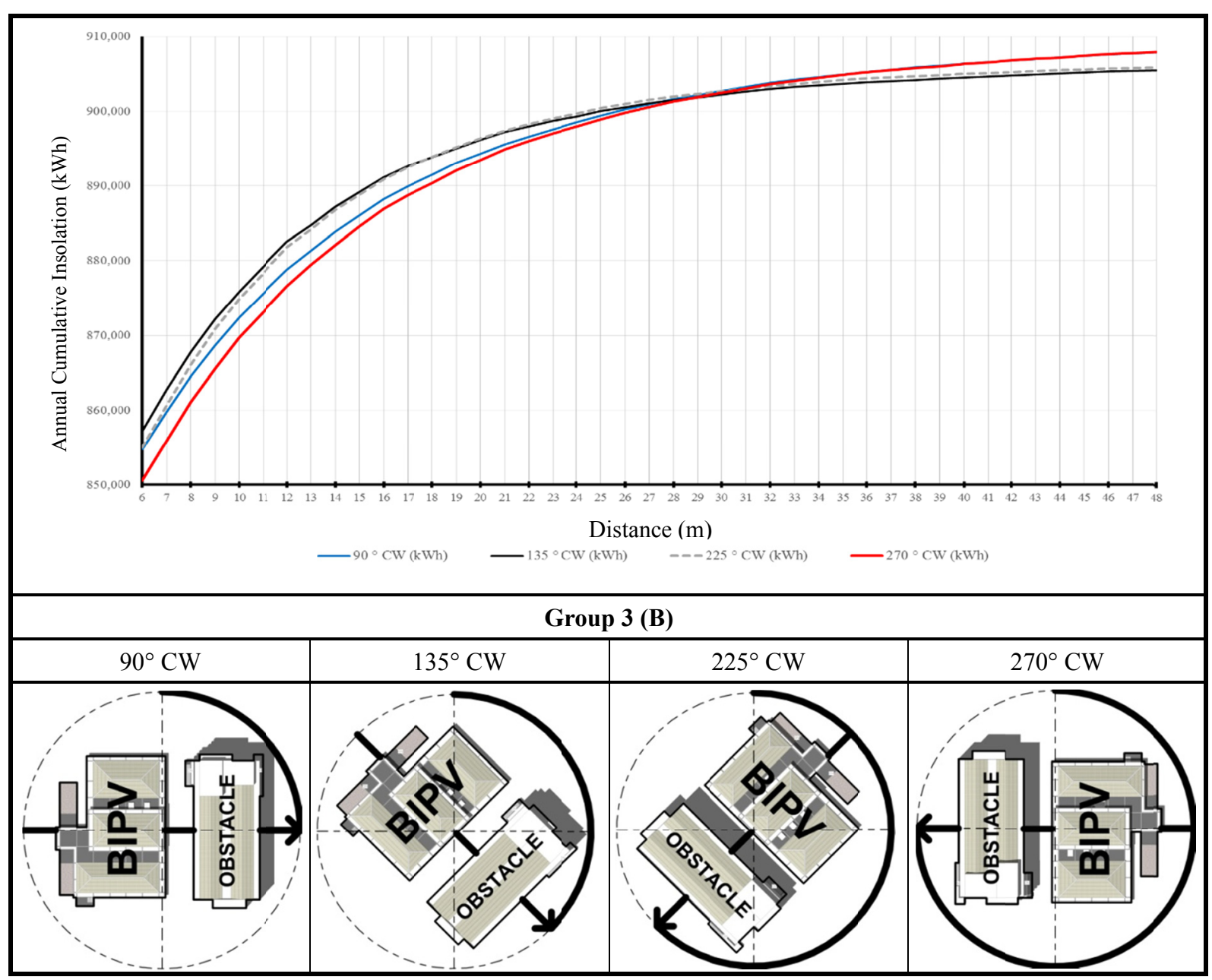

Figure 14. Annual cumulative insolation of Group 3 (B)

\section{References}

Agugiaro, G. (2016). Energy planning tools and CityGML-based 3D virtual city models: experiences from Tento (italy). Applied Geomatics, 8(1), 41-56. https://doi.org/ 10.1007/s12518-015-0163-2

Alam, N., Coors, V., Zlatanova, S., \& Oosterom, P. (2012). Shadow effect on photovoltaic potentiality analysis using 3D city models. XXII ISPRS Congress (pp. 209-214). Melbourne, Australia: International Archives of the Photogrammetry, Remote Sensing and Spatial Information Sciences. Retrieved from http://repository.tudelft.nl/islandora/object/uuid:23fa329e-d6db-46ef-a08d-8a7ea06dde4a?collection=research

Alonso-Garcia, M. C., Ruiz, J. M., \& Hermann, W. (2006, October). Computer simulation of shading effects in photovoltaic arrays. Renewable Energy, 31(12), 1986-1993. https://doi.org/10.1016/j.renene.2005.09.030

Asl, M. R., Zarrinmehr, S., Bergin, M., \& Yan, W. (2015, December). BPOpt: A framework for BIM-based performance optimization. Energy and Buildings, 108, 401-412. https://doi.org/10.1016/j.enbuild.2015.09.011

Attia, S., De Herde, A., Gratia, E., \& Hensen, J. L. (2013). Achieving informed decision-making for net zero energy buildings design using building performance simulation tools. Building Simulation, 6(1), 3-21. https://doi.org/10.1007/s12273-013-0105-z

Autodesk Sustainability Workshop. (2017). Project Phases \& Level of Development. Retrieved from Autodesk Sustainability

Workshop: https://sustainabilityworkshop.autodesk.com/buildings/project-phases-level-development

Bai, J., Cao, Y., Hao, H., Zhang, Z., Liu, S., \& Cao, F. (2015). Characteristic output of PV systems under partial shading or mismatch conditions. Solar Energy, 112, 41-54. https://doi.org/10.1016/j.solener.2014.09.048

Bazjanac, V., Maile, T., Rose, C., O'Donnell, J. T., Mrazovic, N., Morrissey, E., \& Welle, B. R. (2011). An assessment of the use of Building Energy Performance Simulation in early design. Proceedings of Building Simulation 2011 (pp. 1579-1585). Sydney: International Building Performance Simulation Association.

Bhattacharjee, S., Noble, D., Kensek, K., \& Schiler, M. (2016). Solar envelope for sites with existing buildings: Determining solar envelope generating principles for sites with existing buidlings. PLEA 2016 32nd International 
Conference on Passive and Low Energy Architecture. 1, pp. 540-546. Los Angeles: PLEA: Passive and Low Energy Architecture. Retrieved from http://www.plea2016.org/download/PLEA\%202016\%20Volume\%201.pdf

BIMForum. (2013). Level of Development Specification Version: 2013. (J. Reinhardt, \& J. Bedrick, Eds.) Retrieved from www.bimforum.org: www.bimforum.org/lod

Biyik, E., Araz, M., Hepbasli, A., Shahrestani, M., Yao, R., Shao, L., . . Atli, Y. B. (2017). A key review of building integrated photovoltaic (BIPV) systems. Engineering Science and Technology, 20, 833-858. http://dx.doi.org/10.1016/j.jestch.2017.01.009

Celik, B., Karatepe, E., Gokman, N., \& Silvestre, S. (2013). A virtual reality study of surrounding obstacles on BIPV systems for estimation of long-term performance of partially shaded PV arrays. Renewable Energy, 60, 402-414. https://doi.org/10.1016/j.renene.2013.05.040

Celik, B., Karatepe, E., Silvestre, S., Gokman, N., \& Chouder, A. (2015, March). Analysis of spatial fixed PV arrays configurations to maximize energy harvesting in BIPV applications. Renewable Energy, 75, 534-540. http://dx.doi.org/10.1016/j.renene.2014.10.041

Chaianong, A., \& Pharino, C. (2015). Outlook and challenges for promoting solar photovoltaic rooftops in Thailand. Renewable and Sustainable Energy Reviews, 48, 356-372. http://dx.doi.org/10.1016/j.rser.2015.04.042

Chen, H.-M., \& Ger, Y.-F. (2014). Integration of Computer-Aided Solar Energy System Design in Building Information Modeling. In R. I. Issa, \& I. Flood (Ed.), Computing in Civil and Building Engineering (2014) (pp. 414-422). Orlando, Florida, United States: American Society of Civil Engineers. https://doi.org/10.1061/9780784413616

Clark, D. R., Klein, S. A., \& Beckman, W. A. (1984). A method for estimating the performance of photovoltaic systems. Solar Energy, 33(6), 551-555. https://doi.org/10.1016/0038-092X(84)90010-0

Clarke, J. A., \& Hensen, J. L. (2015). Integrated building performance simulation: Progress, prospects, and requirements. Building and Environment, 91, 294-306. https://doi.org/10.1016/j.buildenv.2015.04.002

Dixit, M., \& Yan, W. (2015). A building-integrated photovoltaic prototype for calculating solar orientation and solar insolation. Proceeding of BS2015: 14th Conference of International Building Performance Simulation Association (pp. 2002-2009). Hyderabad, India: International Building Performance Simulation Association (IBPSA). Retrieved from http://www.ibpsa.org/proceedings/BS2015/p2724.pdf

Dolara, A., Lazaroiu, G. C., Leva, S., \& Manzolini, G. (2013). Experimental investigation of partial shading scenarios on PV (photovoltaic) modules. Energy, 55, 466-475. http://dx.doi.org/10.1016/j.energy.2013.04.009

Eastman, C., Teicholz, P., Sacks, R., \& Liston, k. (2011). BIM Handbook - A Guide to Building Information Modeling for Owners, Managers, Designers, Engineers, and Contractors. Hoboken, New Jersey: John Wiley \& Sons, Inc.

Egger, S. (2015, December 23). Autodesk Insight 360. Retrieved from BEST Directory: Building Energy Software Tools: http://www.buildingenergysoftwaretools.com/software/autodesk-insight-360

Eke, R., \& Demircan, C. (2015). Shading effect on the energy rating of two identical PV systems on a building fac, ade. Solar Energy, 122, 48-57. http://dx.doi.org/10.1016/j.solener.2015.08.022

Ekici, B. B. (2014). A least squares support vector machine model for prediction of the next day solar insolation for effective use of PV systems. Measurement, 50, 255-262. https://doi.org/10.1016/j.measurement.2014.01.010

Eltawil, M. A., \& Zhao, Z. (2010, January). Grid-connected photovoltaic power systems: Technical and potential problems-A review. Renewable and Sustainable Energy Reviews, 14(1), 112-129. https://doi.org/10.1016/j.rser.2009.07.015

Frontini, F., Bouziri, S. M., Corbellini, G., \& Medici, V. (2016, June). S.M.O Solution: An Innovative Design Approach to Optimize the Output of BIPV Systems Located in Dense Urban Environments. Energy Procedia, 91, 945-953. https://doi.org/10.1016/j.egypro.2016.06.261

Gökmen, N., Hu, W., Hou, P., Chen, Z., Sera, D., \& Spataru, S. (2016, May). Investigation of wind speed cooling effect on PV panels in windy locations. Renewable Energy, 90, 283-290. https://doi.org/10.1016/j.renene.2016.01.017

Goss, B., Cole, I., Betts, T., \& Gottschalg, R. (2014, December). Irradiance modelling for individual cells of shaded solar photovoltaic arrays. Solar Energy, 110, 410-419. https://doi.org/10.1016/j.solener.2014.09.037

Goswami, D. Y., Kreith, F., \& Kreider, J. F. (2000). Principles of Solar Engineering (2nd ed.). Boca Raton, Florida, United States: CRC Press (Taylor and Francis Group).

Gupta, A., Cemesova, A., Hopfe, C. J., Rezgui, Y., \& Sweet, T. (2014). A conceptual framework to support solar PV simulation using an open-BIM data exchange standard. Automation in Construction, 166-181. https://doi.org/10.1016/j.autcon.2013.10.005

Hand, J. W., Crawley, D. B., Donn, M., \& Lawrie, L. K. (2005). Improving the data available to simulation programs. Proceedings of Building Simulation 2005 (pp. 373-380). Montreal, Canada: International Building Performance Simulation Association (IBPSA). 
Hitchcock, R. J., \& Wong, J. (2011). Transforming IFC architectural view BIMs for energy simulation: 2011. Proceedings of Building Simulation 2011 (pp. 1089-1095). Sydney, Australia: International Building Performance Simulation Association.

Hofer, J., Groenewolt, A., Jayathissa, P., Nagy, Z., \& Schlueter, A. (2016). Parametric analysis and systems design of dynamic photovoltaic shading modules. Energy Science and Engineering, 4(2), 134-152. https://doi.org/10.1002/ese3.115

Hong, T., Lee, M., Koo, C., Jeong, K., \& Kim, J. (2017, May 15). Development of method for estimating the rooftop solar photovoltaic (PV) potential by analyzing the available rofftop area using Hillshade analysis. Applied Energy, 194, 320-332. http://dx.doi.org/10.1016/j.apenergy.2016.07.001

Jakica, N. (2017, June 16). State-of-the-art review of solar design tools and methods for assessing daylighting and solar potential for building-integrated photovoltaics. Renewable and Sustainable Energy Reviews, In Press, Corrected Proof. https://doi.org/10.1016/j.rser.2017.05.080

Jelle, B. P., Breivik, C., \& Røkenes, H. D. (2012). Building integrated photovoltaic products: A state-of-the-art review and future research opportunities. Solar Energy Materials \& Solar Cells, 69-96. https://doi.org/10.1016/j.solmat.2011.12.016

Jongudomsuk, P., Srithamrongsawat, S., Patcharanarumol, W., Limwattananon, S., Pannarunothai, S., Vapatanavong, P., . . Fahamnuaypol, P. (2015). The Kingdom of Thailand Health System Review. (V. Tangcharoensathien, Ed.) Health Systems in Transition, 5(5).

Kanters, J. (2015). Planning for solar buildings in urban environments: An analysis of the design process, methods and tools. LUND, Sweden: Lund Rniversity. Retrieved from http://www.ebd.lth.se/fileadmin/energi_byggnadsdesign/Dokt-avhandling_Jouri_webb.pdf

Kanters, J., \& Wall, M. (2014). The impact of urban design decisions on net zero energy solar buildings in Sweden. Urban, Planning and Transport Research, 2(1), 312-332. http://dx.doi.org/10.1080/21650020.2014.939297

Karatepe, E., Boztepe, M., \& Çolak, M. (2007, August). Development of a suitable model for characterizing photovoltaic arrays with shaded solar cells. Solar Energy, 81(8), 977-992. https://doi.org/10.1016/j.solener.2006.12.001

Kensek, K. M. (2014, October). Integration of Environmental Sensors with BIM: case studies using Arduino. Dynamo, and the Revit API. Informes de la Construcción, 66(536), 31-39. https://doi.org/10.3989/ic.13.151

Kim, H., Asl, M. R., \& Yan, W. (2015). Parametric BIM-based Energy Simulation for Buildings with Complex Kinetic Facades. Proceedings of the 33rd eCAADe Conference. 1, pp. 657-664. Vienna, Austria: Education and research in Computer Aided Architectural Design in Europe.

Krygiel, E., \& Nies, B. (2008). Green BIM: Successful Sustainable Design with Building Information Modeling. New Jersey: John Wiley \& Sons.

Kuo, H.-J., Hsieh, S.-H., Guo, R.-C., \& Chan, C.-C. (2016). A verification study for energy analysis of BIPV buildings with BIM. Energy and Buildings, 130, 676-691. https://doi.org/10.1016/j.enbuild.2016.08.048

Kymmell, W. (2008). Building Information Modeling: Planning and Managing Construction Projects with 4D CAD and Simulations . New York: McGraw-Hill.

Ladenhauf, D., Battisti, K., Berndt, R., Eggeling, E., Fellner, D. W., Gratzl-Michlmair, M., \& Ullrich, T. (2015). Computational geometry in the context of building information. Energy and Buildings, 115, 78-84. https://doi.org/10.1016/j.enbuild.2015.02.056

Lam, K.-h., Close, J., \& E.W.C., L. (2006). Dynamic model of BIPV system for performance prediction. Photovoltaic Energy Conversion, Conference Record of the 2006 IEEE 4th World Conference (pp. 2434-2437). Waikoloa, Hawaii: IEEE. https://doi.org/10.1109/WCPEC.2006.279701

Lau, P. (2015). Building Integrated Photovoltaics in Honolulu, Hawai'i: Assessing urban retrofit application for power utilization and energy savings. Honolulu, Hawaii, United States: D.Arch dissertation, The University of Hawai' $i$ at Mānoa. Retrieved from https://scholarspace.manoa.hawaii.edu/bitstream/10125/45602/1/Lau_Parker_Spring\%202015.pdf

Leite, F., Akcamete, A., Akinci, B., Atasoy, G., \& Kiziltas, S. (2011). Analysis of modeling effort and impact of different levels of detail in building information models. Automation in Construction, 601-609. https://doi.org/10.1016/j.autcon.2010.11.027

Limmanee, A., Udomdachanut, N., Songtrai, S., Kaewniyompanit, S., Sato, Y., Nakishi, M., . . Sakamoto, Y. (2016). Field performance and degradation rates of different types of photovoltaic modules: A case study in Thailand. Renewable Energy, 19, 12-17. https://doi.org/10.1016/j.renene.2015.11.088

Liu, B. Y., \& Jordan, R. C. (1960, July). The interrelationship and characteristic distribution of direct, diffuse and total solar radiation. Solar Energy, 4(3), 1-19. https://doi.org/10.1016/0038-092X(60)90062-1

Long, C., Wang, J., Zhou, X., \& Zhang, L. (2014). A definable photovoltaic forecasting model based on BIM for BIPV. 
In G. Lee, Advances in Electrical and Electronics Engineering (pp. 145-150). Ashurst, Southampton, United Kingdom: WIT Press. https://doi.org/10.2495/ICEEE20140171

Masa-bote, D., \& Caamaño-Martín, E. (2014). Methodology for estimating building integrated photovoltaics. Renewable and Sustainable Energy, 492-500. https://doi.org/10.1016/j.rser.2013.12.019

Matthew, G., Jason, G., Melissa, T., Seokho, C., \& Fiona, C. Y. (2013). Building Information Modelling : an international survey. Building Information Modelling : an international survey. In World Building Congress 2013, 5-9 May 2013. Brisbane, QLD: Queensland University of Technology.

Mulcué-Nieto, L. F., \& Mora-López, L. (2015). Methodology to establish the permitted maximum losses due to shading and orientation in photovoltaic applications in buildings. Applied Energy, 137, 37-45. https://doi.org/10.1016/j.apenergy.2014.09.088

Nagy, Z., Svetozarevic, B., Jayathissa, P., Begle, M., Hofer, J., Lydon, G., . . Schlueter, A. (2016). The Adaptive Solar Facade: From concept to prototypes. Frontiers of Architectural Research, 5, 143-156.

Negendahl, K. (2015). Building performance simulation in the early design stage: An introduction to integrated dynamic models. Automation in Construction, 54, 39-53. https://doi.org/10.1016/j.autcon.2015.03.002

Ning, G., Junnan, L., Yansong, D., Zhifeng, Q., Qingshan, J., Weihua, G., \& Geert, D. (2017). BIM-based PV system optimization and deployment. Energy and Buildings, 150, 13-22. http://dx.doi.org/10.1016/j.enbuild.2017.05.082

Norton, B., Eames, P. C., Mallick, T. K., Huang, M. J., McCormack, S. J., Mondol, J. D., \& Yohanis, Y. G. (2011). Enhancing the performance of building integrated photovoltaics. Solar Energy, 1629-1664. https://doi.org/10.1016/j.solener.2009.10.004

O'Donnell, J., See, R., Rose, C., Maile, T., Bazjanac, V., \& Haves, P. (2011). Simmodel: A domain data model for whole building energy simulation. SimBuild 2011. Sydney, Australia: International Building Performance Simulation Association (IBPSA).

Ramli, M. A., Twaha, S., Ishaque, K., \& Al-Turki, Y. A. (2017). A review on maximum power point tracking for photovoltaic systems with and without shading conditions. Renewable and Sustainable Energy Reviews, 67, 144-159. http://dx.doi.org/10.1016/j.rser.2016.09.013

Shen, Y. T., \& Lu, P. W. (2016). The development of kinetic facade units with BIM-based active control system for the adaptive building energy performance service. International Conference of the Association for Computer-Aided Architectural Design Research in Asia CAADRIA 2016 (pp. 517-526). Hong Kong: The Association for Computer-Aided Architectural Design Research in Asia (CAADRIA).

Shukla, A. K., Sudhakar, K., \& Baredar, P. (2016). A comprehenshive review on design of building integrated photovoltaic system. Energy and Building, 128, 99-110. https://doi.org/10.1016/j.enbuild.2016.06.077

Sinovoltaics. (2014, October 21). Difference Solar Radiation and Solar Insolation Explained. Retrieved from Sinovoltaics: http://sinovoltaics.com/learning-center/basics/solar-radiation-solar-insolation/

Solarinsolation.org. (2012, January 15). Solar insolation, what is it? Retrieved from Solar Insolation: http://solarinsolation.org/

Somboonwit, N. (2011). Modeling for building energy performance improvement in accordance with the local climatic settings: A case of a generalizable building design of intermediate health care facilities in Thailand. Proceedings of Building Simulation 2011 (pp. 1623-1630). Sydney, Australia: International Building Performance Simulation Association (IBPSA).

Somboonwit, N., \& Sahachaisaeree, N. (2012). Healthcare Building: Modelling the impacts of local factors for building energy performance improvement in Thailand. Procedia - Social and Behavioral Sciences, 50, 549-562. https://doi.org/10.1016/j.sbspro.2012.08.058

Somboonwit, N., Boontore, A., \& Rugwongwan, Y. (2017). Obstacles to the Automation of Building Performance Simulation: Adaptive Building Integrated Photovoltaic Design. 5th AicQol2017. 2, pp. 343-354. Bangkok, Thailand: E-BPJ. http://dx.doi.org/10.21834/e-bpj.v2i5.619

Stine, D. (2015, November 20). Building Performance Analysis in Revit 2016 R2 with Autodesk Insight 360. Retrieved from AECbytes: http://aecbytes.com/tipsandtricks/2015/issue76-revit.html

Strong, S. (2011, December 27). Building Integrated Photovoltaic (BIPV). Retrieved July 25, 2015, from Whole Building Design Guide: http://www.wbdg.org/resources/bipv.php

Tripathy, M., Yadav, S., Sadhu, P., \& Panda, S. (2017, April). Determination of optimum tilt angle and accurate insolation of BIPV panel influenced by adverse effect of shadow. Renewable Energy, 104, 211-223. https://doi.org/10.1016/j.renene.2016.12.034

Volk, R., Stengel, J., \& Schultmann, F. (2014). Building Information Modeling (BIM) for existing buildings Literature review and future needs. Automation in Construction, 109-127. https://doi.org/10.1016/j.autcon.2013.10.023

Waewsak, J., Chancham, C., Mani, M., \& Gagnon, Y. (2014). Estimation of monthly mean daily global solar radiation 
over Bangkok, Thailand using Artificial Neural Networks. Energy Procedia, 57, 1160-1168. https://doi.org/10.1016/j.egypro.2014.10.103

Welle, B., Haymaker, J., \& Rogers, Z. (2011). ThermalOpt: A methodology for BIM-based passive thermal multidisciplinary design optimization. Standford, CA: Center for Integrated Facility Engineering (CIFE), Standford University.

Woyte, A., Nijs, J., \& Belmans, R. (2003). Partial shadowing of photovoltaic arrays with different system configurations: literature review and field test results. Solar Energy, 74, $217-233$. https://doi.org/10.1016/S0038-092X(03)00155-5

Yang, R. J. (2015). Overcoming technical barriers and risks in the application of building integrated photovoltaic (BIPV): hardware and software strategies. Automation in Construction, 92-102. https://doi.org/10.1016/j.autcon.2014.12.005

Yoo, S.-H. (2011). Simulation for an optimal application of BIPV through parameter variation. Solar Energy, 85, 1291-1301. https://doi.org/10.1016/j.solener.2011.03.004

Yoon, J.-H., Song, J., \& Lee, S.-J. (2011, May). Practical application of building integrated photovoltaic (BIPV) system using transparent amorphous silicon thin-film PV module. Solar Energy, 85(5), 723-733. https://doi.org/10.1016/j.solener.2010.12.026

Zeil, H. (2017, August 4). Sun. Retrieved from https://www.nasa.gov/mission_pages/sdo/science/solar-irradiance.html

Zomer, C., \& Rüther, R. (2017). Simplified method for shading-loss analysis in BIPV systems - part 1: Theoretical study. Energy and Buildings, 141, 69-82. https://doi.org/10.1016/j.enbuild.2017.02.042

\section{Appendix A}

The Simulated Annual Cumulative Insolation Results of All 8 Orientations

\begin{tabular}{|c|c|c|c|c|c|c|c|c|}
\hline $\begin{array}{l}\text { Distance } \\
(\mathrm{m})\end{array}$ & $\begin{array}{c}0^{\circ} \mathrm{CW} \\
(\mathrm{kWh})\end{array}$ & $\begin{array}{c}45^{\circ} \mathrm{CW} \\
(\mathrm{kWh})\end{array}$ & $\begin{array}{c}90{ }^{\circ} \mathrm{CW} \\
(\mathrm{kWh})\end{array}$ & $\begin{array}{c}135^{\circ} \mathrm{CW} \\
(\mathrm{kWh})\end{array}$ & $\begin{array}{c}180^{\circ} \mathrm{CW} \\
(\mathrm{kWh})\end{array}$ & $\begin{array}{c}225^{\circ} \mathrm{CW} \\
(\mathrm{kWh})\end{array}$ & $\begin{array}{c}270^{\circ} \mathrm{CW} \\
(\mathrm{kWh})\end{array}$ & $\begin{array}{c}315^{\circ} \mathrm{CW} \\
(\mathrm{kWh})\end{array}$ \\
\hline 6 & 893,937 & 884,637 & 854,723 & 857,213 & 881,863 & 854,965 & 850,526 & 883,266 \\
\hline 7 & 894,615 & 886,955 & 859,743 & 862,680 & 886,524 & 860,655 & 855,919 & 885,765 \\
\hline 8 & 895,249 & 889,031 & 864,541 & 867,832 & 890,128 & 866,069 & 861,096 & 887,957 \\
\hline 9 & 895,782 & 890,834 & 868,668 & 872,153 & 892,730 & 870,874 & 865,575 & 889,799 \\
\hline 10 & 896,293 & 892,438 & 872,458 & 875,896 & 894,354 & 874,920 & 869,729 & 891,398 \\
\hline 11 & 896,726 & 893,719 & 875,602 & 879,221 & 895,229 & 878,368 & 873,197 & 892,957 \\
\hline 12 & 897,150 & 894,986 & 878,827 & 882,524 & 896,073 & 881,803 & 876,610 & 894,065 \\
\hline 13 & 897,509 & 895,980 & 881,362 & 884,757 & 896,741 & 884,212 & 879,454 & 895,199 \\
\hline 14 & 897,860 & 896,988 & 883,841 & 887,178 & 897,345 & 886,800 & 882,097 & 896,150 \\
\hline 15 & 898,185 & 897,817 & 886,107 & 889,173 & 897,781 & 888,810 & 884,613 & 897,087 \\
\hline 16 & 898,478 & 898,605 & 888,254 & 891,126 & 898,168 & 890,866 & 886,912 & 897,856 \\
\hline 17 & 898,742 & 899,243 & 889,972 & 892,624 & 898,547 & 892,476 & 888,751 & 898,547 \\
\hline 18 & 898,978 & 899,828 & 891,469 & 893,852 & 898,802 & 893,835 & 890,327 & 899,128 \\
\hline 19 & 899,229 & 900,457 & 893,036 & 895,039 & 899,060 & 895,145 & 892,053 & 899,738 \\
\hline 20 & 899,437 & 900,896 & 894,331 & 896,202 & 899,270 & 896,366 & 893,476 & 900,244 \\
\hline 21 & 899,646 & 901,327 & 895,579 & 897,192 & 899,482 & 897,403 & 894,909 & 900,699 \\
\hline 22 & 899,826 & 901,728 & 896,604 & 897,995 & 899,662 & 898,258 & 895,978 & 901,145 \\
\hline 23 & 900,002 & 902,087 & 897,590 & 898,719 & 899,838 & 899,024 & 897,033 & 901,505 \\
\hline 24 & 900,168 & 902,497 & 898,514 & 899,310 & 900,004 & 899,686 & 897,979 & 901,858 \\
\hline 25 & 900,340 & 902,817 & 899,455 & 900,040 & 900,176 & 900,427 & 898,947 & 902,183 \\
\hline 26 & 900,486 & 903,096 & 900,239 & 900,554 & 900,322 & 900,982 & 899,825 & 902,460 \\
\hline 27 & 900,627 & 903,360 & 900,934 & 901,085 & 900,463 & 901,549 & 900,587 & 902,745 \\
\hline 28 & 900,763 & 903,617 & 901,640 & 901,490 & 900,599 & 901,949 & 901,335 & 903,007 \\
\hline 29 & 900,880 & 903,847 & 902,140 & 901,864 & 900,716 & 902,317 & 901,873 & 903,249 \\
\hline 30 & 900,990 & 904,042 & 902,712 & 902,215 & 900,826 & 902,653 & 902,461 & 903,476 \\
\hline 31 & 901,101 & 904,280 & 903,227 & 902,601 & 900,937 & 903,028 & 903,029 & 903,699 \\
\hline 32 & 901,214 & 904,454 & 903,771 & 902,928 & 901,050 & 903,347 & 903,602 & 903,888 \\
\hline 33 & 901,312 & 904,635 & 904,199 & 903,215 & 901,148 & 903,639 & 904,049 & 904,051 \\
\hline
\end{tabular}




\begin{tabular}{ccccccccc}
\hline $\begin{array}{c}\text { Distance } \\
(\mathrm{m})\end{array}$ & $\begin{array}{c}0^{\circ} \mathrm{CW} \\
(\mathrm{kWh})\end{array}$ & $\begin{array}{c}45^{\circ} \mathrm{CW} \\
(\mathrm{kWh})\end{array}$ & $\begin{array}{c}90^{\circ} \mathrm{CW} \\
(\mathrm{kWh})\end{array}$ & $\begin{array}{c}135^{\circ} \mathrm{CW} \\
(\mathrm{kWh})\end{array}$ & $\begin{array}{c}1800^{\circ} \mathrm{CW} \\
(\mathrm{kWh})\end{array}$ & $\begin{array}{c}225^{\circ} \mathrm{CW} \\
(\mathrm{kWh})\end{array}$ & $\begin{array}{c}270^{\circ} \mathrm{CW} \\
(\mathrm{kWh})\end{array}$ & $\begin{array}{c}315^{\circ} \mathrm{CW} \\
(\mathrm{kWh})\end{array}$ \\
\hline 34 & 901,397 & 904,773 & 904,569 & 903,440 & 901,233 & 903,868 & 904,450 & 904,193 \\
35 & 901,479 & 904,917 & 904,919 & 903,671 & 901,315 & 904,138 & 904,830 & 904,327 \\
36 & 901,564 & 905,064 & 905,260 & 903,855 & 901,401 & 904,356 & 905,188 & 904,460 \\
37 & 901,630 & 905,156 & 905,511 & 904,013 & 901,467 & 904,513 & 905,453 & 904,558 \\
38 & 901,714 & 905,313 & 905,841 & 904,162 & 901,550 & 904,674 & 905,769 & 904,679 \\
39 & 901,772 & 905,397 & 906,050 & 904,316 & 901,608 & 904,806 & 905,997 & 904,774 \\
40 & 901,847 & 905,534 & 906,347 & 904,490 & 901,681 & 904,980 & 906,291 & 904,895 \\
41 & 901,897 & 905,607 & 906,527 & 904,617 & 901,733 & 905,080 & 906,501 & 904,982 \\
42 & 901,965 & 905,706 & 906,796 & 904,774 & 901,801 & 905,237 & 906,774 & 905,073 \\
43 & 902,020 & 905,804 & 907,000 & 904,885 & 901,857 & 905,343 & 906,976 & 905,165 \\
44 & 902,071 & 905,873 & 907,188 & 905,039 & 901,908 & 905,453 & 907,173 & 905,238 \\
45 & 902,125 & 905,956 & 907,372 & 905,170 & 901,961 & 905,568 & 907,392 & 905,337 \\
46 & 902,176 & 906,022 & 907,562 & 905,287 & 902,012 & 905,679 & 907,603 & 905,408 \\
47 & 902,222 & 906,090 & 907,708 & 905,370 & 902,058 & 905,778 & 907,756 & 905,408 \\
48 & 902,273 & 906,161 & 907,856 & 905,454 & 902,109 & 905,860 & 907,937 & 905,551 \\
\hline
\end{tabular}

\section{Copyrights}

Copyright for this article is retained by the author(s), with first publication rights granted to the journal.

This is an open-access article distributed under the terms and conditions of the Creative Commons Attribution license (http://creativecommons.org/licenses/by/4.0/). 